\title{
O PROTAGONISMO DO JUDICIÁRIO NO MUNDO CONTEMPORÂNEO E ALGUMAS DE SUAS RAZÕES
}

THE PROTAGONISM OF THE JUDICIARY IN THE CONTEMPORARY WORLD AND SOME OF ITS REASONS

EL PROTAGONISMO DEL PODER JUDICIAL EN EL MUNDO CONTEMPORANEO Y ALGUNAS DE SUS RAZONES

\section{Eugênio Facchini Neto ${ }^{1}$}

Resumo: O presente ensaio versa sobre algumas das razões que ajudam a explicar o maior protagonismo do Poder Judiciário no mundo contemporâneo. Após evidenciar os sinais desse protagonismo e de elencar alguns conjuntos de causas, ele foca especificamente nas razões político-estruturais do aumento da importância do judiciário, tais como as características do constitucionalismo moderno, a nova organização do poder, a crise do poder legislativo, as novas características da legislação, o advento e a crise do welfare state, a questão do controle do poder, a ideia de democracia participativa e a necessidade de proteção das minorias e dos direitos fundamentais. Trata-se de uma pesquisa que transcende a experiência brasileira para focar algo que atinge todas as democracias contemporâneas. O método utilizado é o da pesquisa bibliográfica, sem focar um autor ou um ponto de vista específico, optando por uma ampla pesquisa sobre os pontos

1 Doutor em Direito Comparado (Florença/ltália), Mestre em Direito Civil (USP). Licenciado em Estudos Sociais. Professor Titular dos Cursos de Graduação, Mestrado e Doutorado em Direito da PUC/RS. Professor e ex-diretor da Escola Superior da Magistratura/AJURIS. Desembargador no TJ/RS. E-mail: facchini@tj.rs.gov.br 
de vista de autores distintos, de variadas nacionalidades e distinta formação acadêmica. Palavras-chave: Judiciário - protagonismo - judicialização - poder.

Abstract: This essay addresses some of the factors that help to explain the greater role of the Judiciary in the contemporary world. After highlighting the signs of this leading role, and listing a number of probable causes, it then focuses specifically on the political-structural reasons for the increased importance of the judiciary, such as the characteristics of modern constitutionalism, the new organization of power, the crisis of legislative power, the new characteristics of the legislation, the advent and crisis of the welfare state, the issue of power control, the idea of participatory democracy and the need to protect minorities and fundamental rights. It is a study that transcends the Brazilian experience and focuses on all contemporary democracies. The method used is bibliographic research, without focusing on an author or a specific point of view, opting instead for a broad survey of the points of view of different authors, of different nationalities and different academic backgrounds. Keywords: Judiciary - protagonism - judicialization - power.

Resumen: El presente ensayo consiste sobre algunas de las razones que ayudan a explicar el mayor protagonismo del Poder Judicial en el mundo contemporáneo. Después de evidenciar los signos de ese protagonismo y de enumerar algunos conjuntos de causas, el mismo enfoca específicamente en las razones político estructurales del aumento de la importancia del poder judicial, tales como las características del constitucionalismo moderno, la nueva organización del poder, la crisis del poder legislativo, las nuevas características de la legislación, el adviento y la crisis del welfare state, la cuestión del control del poder, la idea de democracia participativa y la necesidad de protección de las menorías y de los derechos fundamentales. Se trata de una investigación que transciende a la experiencia brasileña para enfocar algo que alcanza todas las democracias contemporáneas. El método utilizado es el de la investigación bibliográfica, sin destacar un autor o un punto de vista específico, optando por una amplia búsqueda sobre los puntos de vista de distintos autores, de varias nacionalidades y distinta formación académica. Palabras-clave: Poder Judicial - protagonismo - judicialización - poder.

\section{INTRODUÇÃO}

aumento da complexidade dos sistemas políticos, das novas formas de relações sociais, bem como do impacto das novas tecnologias na vida da sociedade, traz consigo uma expansão regulatória e o aumento do 
papel do Direito como técnica de disciplina e orientação dos poderes públicos e da vida social. Isso acarreta a inevitável expansão crescente do papel da jurisdição, uma vez que quanto mais relevante é o papel do Direito na conformação da atuação dos órgãos públicos e na condução da sociedade, maior é a possibilidade da judicialização destas questões. Este é um fenômeno comum a todas as democracias avançadas².

O fenômeno é complexo e envolve uma ampla gama de explicações. Algumas delas são de ordem científico-culturais, tais como a superação do legalismo positivista, que identificava no legislador a verdadeira locomotiva do Direito, vendo no Juiz a figura montesquiana de mera "boca da lei" (bouche de la loi). A crise da teoria das fontes acabou repercutindo enormemente na jurisdição, percebendose a inafastável criatividade do momento jurisprudencial da interpretação e da aplicação da lei, com o consequente crescimento do papel do juiz.

Outras razões são de natureza, por assim dizer, sociológica, em virtude de uma maior diversidade da extração social da magistratura, espelho de uma sociedade mais pluralista, ao contrário de um passado em que os integrantes do Judiciário eram praticamente todos integrantes das classes social mais elevadas e que, por isso, compartilhavam os valores caros à manutenção da ordem estabelecida. Parcela significativa dos juízes contemporâneos, em várias partes do mundo, começa a ensaiar a possibilidade de serem porta-vozes não só da segurança dos que já têm, mas também da esperança dos muitos que ainda não têm, e que veem no Judiciário uma possibilidade de acesso a certos direitos a prestações do Estado, como cidadãos, e de fazer respeitar, pela sociedade, sua dignidade como seres humanos.

Além dessas, existem algumas razões que poderiam ser denominadas de políticoestruturais. Sob esse rótulo, pode-se referir como produzindo impactos na jurisdição e no papel do juiz, o constitucionalismo moderno, que coloca a salvo do próprio Legislativo os direitos fundamentais, colocando-os especialmente

2 Discorrendo sobre a judicialização das relações sociais, O'Donnell explica que tal fenômeno está provavelmente ligado ao fenômeno conexo da juridificação das relações sociais, ou seja, o crescente grau em que as relações sociais, antes deixadas a uma regulamentação autônoma ou informal, estão sendo conformadas e reguladas por regras jurídicas. Quanto mais as relações sociais são normatizadas, maiores são as chances de que disputas que inevitavelmente surgirão venham a ser levadas aos tribunais para uma solução com base em parâmetros jurídicos. Nesses termos, Guillermo O'Donnell, "Afterword", in: SIEDER, Rachel; SCHJOLDEN, Line; ANGELL, Alan (Ed.), The Judicialization of Politics in Latin America, p. 293. 
sob a proteção do Judiciário, a nova organização do poder, mais descentralizado e menos homogêneo, com enorme crescimento da estrutura administrativa do Estado e do agigantamento dos poderes regulatórios e legislativos, faz com que necessariamente também o Judiciário deva ser fortalecido, de forma a se manter o equilíbrio entre poderes, a crise do poder legislativo, ou seja, o legislativo já não consegue prover a sociedade com normas atualizadas no mesmo ritmo das suas necessidades, já que esta gera novos problemas e adota novos valores num ritmo bem mais veloz do que a capacidade do legislador de lhes fazer frente, fazendo com que o judiciário, malgré lui-même, se torne o atualizador preferencial do Direito.

A própria legislação adquire novas características, dotando-se de normas de textura mais abertas, como princípios, cláusulas gerais, conceitos indeterminados, o que aumenta enormemente o poder do intérprete, especialmente do juiz, de fixar-lhes o conteúdo. O welfare state e sua crise igualmente acarretaram substanciais efeitos no acesso à justiça, pela população desejosa de obter ou manter direitos sociais. O problema do controle do poder constitui desde há muito tempo uma questão que concerne o Judiciário, a ponto de se ter cunhado a expressão 'judicialização da política'. Modernamente, com a crise ética que atinge o setor político e administrativo de muitas nações, o Judiciário é mais insistentemente chamado à cena. O direito também está adotando novas funções, como a promocional, que em vez de apenas reprimir o ilícito e chancelar o lícito, procura incentivar ou desincentivar condutas, o que igualmente acarreta uma alteração da função do próprio judiciário. A própria concepção de democracia está se alterando, não mais bastando a simples democracia representativa. Especialmente a denominada democracia participativa, ao exigir a participação popular também no processo de tomada de decisões, ou com poder para bloquear determinadas iniciativas, permite que segmentos da sociedade se utilizem da arena judiciária para tentar influir na gestão da coisa pública. A necessidade de proteger as minorias e de garantir os direitos fundamentais igualmente acarreta um novo perfil de Judiciário, que muitas vezes deve estar disposto a se interpor entre o indivíduo, isoladamente ou em grupos, e o aparato estatal ou a própria maioria da população, buscando garantir-lhes a proteção prevista na Constituição. Tudo isso acarreta novas funções para o Judiciário. 
É desses aspectos que trata esse despretensioso ensaio, que de original tem apenas o fato de que se procura condensar, sob esse rótulo, certas ideias que se encontram dispersas entre juristas e cientistas sociais, buscando dar uma sistematização a esse fenômeno perceptível do aumento da importância do Poder Judiciário no Estado e na sociedade contemporânea.

\section{Razões político-estruturais do aumento da importância do judiciário}

Em países nos quais as instituições democráticas funcionam normalmente, mesmo quando o judiciário age no normal exercício de suas funções rotineiras, apreciando casos cíveis (v.g. responsabilidade civil) ou criminais, pode ele causar impacto no mundo político. Em interessante livro ${ }^{3}$ sobre os tribunais, a lei e a política, em perspectiva comparada, colocou-se inicialmente a pergunta sobre se os países analisados - Estados Unidos, Inglaterra, França, Alemanha e Japão seriam significativamente diferentes, se não houvesse tribunais, ou se os mesmos operassem sob regras diversas das existentes. Após analisar as experiências de todos esses países, constatou-se que muitos eventos políticos teriam tido um desfecho muito diverso se não fosse a atuação do Judiciário. Como exemplo dos casos estudados, afirmou-se que o partido socialista francês não teria perdido o poder, não fosse a atuação dos juízes criminais que revelaram o escândalo do sangue contaminado com AIDS que levou à morte milhares de pessoas; que o partido liberal-democrático japonês não teria igualmente sido alijado do poder, não fosse a investigação de corrupção por promotores independentes, bem como se não tivesse sido manchado pelo caso Minamata e outros casos de poluição industrial, em que a justiça evidenciou o descaso e a indiferença do governo; na Alemanha, inúmeros casos julgados pela corte constitucional ajudaram a definir a organização política da Alemanha do pós-guerra; na Inglaterra, as cortes criminais desempenharam papel central na luta contra os terroristas norteirlandeses, ao passo que nos Estados Unidos não há a menor dúvida de que decisões da Suprema Corte definiram agendas políticas e sociais daquele país por décadas. Não foram estudadas no referido livro as experiências italianas da década de 90 e a brasileira dos últimos anos. Caso tivessem sido, certamente seria mencionado o fato da operação italiana Mani Pulite, no giro de poucos anos, 3 Herbert Jacob, Courts, Law \& Politics in Comparative Perspective, p. 389. 
que alterou radicalmente o espectro político italiano, defenestrando as forças políticas hegemônicas na Itália desde o final da segunda guerra mundial - com a extinção do partido da democracia cristã (DC) e do partido democrático della sinistra (PDS) - em razão da extensa corrupção que grassou entre seus quadros políticos e administrativos, juntamente com a elite empresarial italiana. Também seriam referidos os efeitos de processos judiciais no Brasil, fruto de investigações independentes levadas a efeito pelo Ministério Público, as quais desencadearam um abalo para o então partido hegemônico brasileiro, o PT, culminando com o afastamento de uma presidente - tudo fruto dos desdobramentos dos processos do Mensalão e principalmente da chamada Operação Lava-Jato.

Indicam-se duas razões fundamentais para esta expansão do papel do Direito e da jurisdição, ambas estruturais e irreversíveis. Uma é a mudança da estrutura do sistema jurídico, ocorrida na segunda metade do século XX, com a sua evolução em direção ao Estado constitucional de direito. A outra deriva da mudança da estrutura do sistema político, em razão do desenvolvimento contemporâneo do Estado social, com o incremento da intervenção do Estado na economia e na sociedade ${ }^{4}$.

Essas mudanças, como se sabe, não são restritas a um determinado país ou área geográfica. A globalização (ou mundialização, como preferem os franceses) que inicia pelo comércio, pela economia, pela cultura, chega também ao direito. Institutos jurídicos circulam com cada vez mais intensidade. Também os judiciários nacionais cada vez mais dialogam com seus congêneres estrangeiros. Decisões de uma corte suprema são citadas e por vezes seguidas em outros países. Chega-se a dizer que "os juízes se afirmam como agentes de primeiro plano na mundialização do direito" ${ }^{5}$.

Em excelente estudo de um grupo de juscomparatistas, de mais de novecentas páginas ${ }^{6}$, sobre o tema das cortes constitucionais como legisladores positivos, analisando a experiência de cerca de trinta países, chegou-se à conclusão de que as cortes constitucionais progressivamente assumiram papéis que antigamente correspondiam apenas ao constituinte ou ao legislador ordinário. Em alguns casos

$4 \quad$ Luigi Ferrajoli, "Giurisdizione e democrazia”, Democrazia e Diritto, 1997, n. 1, p. 285.

5 Julie Allard e Antoine Garapon, Les juges dans la mondialisation - La nouvelle révolution du droit, p. 23.

6 Allan R. Brewer-Carías, Constitutional Courts as Positive Legislators - A Comparative Law Study, p. 921/923. 
aqueles tribunais supremos descobriram ou deduziram normas constitucionais, especialmente no campo dos direitos humanos, que não estavam expressamente consagradas nas Constituições ou que nem poderiam ter sido consideradas pela intenção do legislador originário, no caso de constituições antigas (como a norteamericana). Em outros casos, as cortes desempenharam funções legislativas ao complementarem a obra do legislador, preenchendo lacunas e omissões legislativas, ou enviando parâmetros para o legislador, compelindo-o a editar normas. Ao assim agir, as cortes superiores frequentemente examinam as decisões umas das outras, aplicando modelos de raciocínio já testados e aprovados em outros países. Juízes não lidam com proposições puramente teóricas. Eles estão voltados à resolução de casos reais e práticos. E como num mundo cada vez mais globalizado os casos tendem a se reproduzir em escala global, é razoável que se observem as experiências alheias, especialmente naqueles casos em que há omissão legislativa. Afinal, como referiu a U.S. Justice Ruth B. Ginsburg, "por que não deveríamos levar em consideração a sabedoria de um juiz estrangeiro ao menos com a mesma atenção com que lemos um artigo doutrinário escrito por um professor?"7.

Esse maior protagonismo do Judiciário no mundo contemporâneo frequentemente desagrada alguns setores, quando suas intenções e desejos são contrariados por decisões judiciais. Mas tais contrariedades tendem a ser naturalmente absorvidas e raramente deixam cicatrizes permanentes. Afinal, como pontuou Charles Gardner Geyh ${ }^{8}$, parafraseando Lincoln, o Judiciário pode deixar furiosa parte das pessoas durante todo o tempo e todas as pessoas durante parte do tempo, mas não pode deixar todos furiosos durante todo o tempo, sem colocar em risco sua própria sobrevivência.

Como tudo aquilo que não é regido por uma lógica matemática e, portanto, se abre a tomadas de posição nem sempre coincidentes, também a atuação dos juízes ao propiciar garantia aos direitos das partes que os acessam pode ser elogiada por alguns e criticadas por outros, sempre amparadas por argumentos razoáveis. Discorrendo sobre o ativismo da Corte de Justiça Europeia9, Mark Dawson refere 7 Adam Liptak, "Ginsburg Shares Views on Influence of Foreign Law on Her Court, and Vice Versa", in New York Times, April 12, 2009, p. 14.

8 Charles Gardner Geyh, When Courts \& Congress Collide, p. 19.

9 Tribunal com sede em Luxemburgo, integrado por um juiz oriundo de cada país membro da União Eu- 
que posições mais ativistas dos tribunais podem ser lidas de duas formas: ao garantir que indivíduos tenham garantidas suas pretensões baseadas diretamente no direito europeu, em detrimento dos direitos nacionais, a Corte nada mais estaria fazendo do que garantir às pessoas o acesso à justiça para fazer valer direitos individuais. Já outra leitura por ele indicada estaria a apontar que os juízes, ao deduzirem direitos de vagos princípios positivados, estariam a usurpar poderes da comunidade política, subvertendo as preferências expressas por esta ${ }^{10}$.

Distinguindo a judicialização do fenômeno conexo do ativismo judicial, assim se pronunciou Barroso:

A judicialização e o ativismo judicial são primos. Vêm, portanto, da mesma família, freqüentam os mesmos lugares, mas não têm as mesmas origens. Não são gerados, a rigor, pelas mesmas causas imediatas. A judicialização, no contexto brasileiro, é um fato, uma circunstância que decorre do modelo constitucional que se adotou, e não um exercício deliberado de vontade política. Em todos os casos referidos acima, o Judiciário decidiu porque era o que the cabia fazer, sem alternativa. Se uma norma constitucional permite que dela se deduza uma pretensão, subjetiva ou objetiva, ao juiz cabe dela conhecer, decidindo a matéria. Já o ativismo judicial é uma atitude, a escolha de um modo específico e proativo de interpretar a Constituição, expandindo o seu sentido e alcance. Normalmente ele se instala em situações de retração do Poder Legislativo, de um certo descolamento entre a classe política e a sociedade civil, impedindo que as demandas sociais sejam atendidas de maneira efetiva. A idéia de ativismo judicial está associada a uma participação mais ampla e intensa do Judiciário na concretização dos valores e fins constitucionais, com maior interferência no espaço de atuação dos outros dois Poderes. A postura ativista se manifesta por meio de diferentes condutas, que incluem: (i) a aplicação direta da Constituição a situações não expressamente contempladas em seu texto e independentemente de manifestação do legislador ordinário; (ii) a declaração de inconstitucionalidade de atos normativos emanados do legislador, com base em critérios menos rígidos que os de patente e ostensiva violação da Constituição; (iii) a imposição de condutas ou de abstenções ao poder público, notadamente em matéria de políticas públicas. ${ }^{11}$

ropeia, que tem por função zelar que o direito europeu seja interpretado e aplicado da mesma forma em todos os países da UE e garantir que as instituições e os países da UE respeitem e acatem a supremacia do direito europeu.

10 Mark Dawson, “The political face of judicial activism: Europe's law-politics imbalance”, in: DAWSON, Mark; DE WITTE, Bruno; MUIR, Elise. (Ed.). Judicial Activism at the European Court of Justice, p. $11 / 12$.

11 Luís Roberto Barroso, “Judicialização, ativismo judicial e legitimidade democrática”, in http://www.conjur.com.br/2008-dez-22/judicializacao_ativismo_legitimidade_democratica. 
Passa-se, agora, a expor, de forma mais articulada, as razões político-estruturais de tal expansão.

\section{O constitucionalismo moderno}

A primeira revolução na história da modernidade jurídica, correspondente ao surgimento do Estado moderno, realizou-se com a afirmação do princípio da legalidade e da onipotência do legislador. Disso decorria a identificação da validade das leis com a sua positividade, ou seja, com a sua emanação pelas formas previstas no ordenamento. "Autorictas non veritas facit legem" (a autoridade, não a verdade, faz as leis), havia declarado Hobbes, invertendo a velha máxima jusnaturalista "veritas non auctoritas facit legem" (a verdade, não a autoridade, faz as leis). Ao princípio da onipotência do legislador correspondia, por outro lado, a ideia da onipotência da política - ou seja, do primado da política sobre o Direito - e, correlatamente, uma concepção toda política e formal da democracia, identificada com a vontade da maioria, expressa por meio de seus representantes, os políticos periodicamente eleitos pelo povo.

O constitucionalismo originário é o constitucionalismo do Estado Liberal burguês. Este se assentava na redução do Estado às tarefas de garantia da liberdade, da segurança e da ordem pública, pressupunha a separação Estado/sociedade, e remetia a economia à autoridade do mercado ${ }^{12}$.

Assim Comparato descrevia esse modelo:

...segundo o modelo do constitucionalismo liberal, não compete ao Estado guiar a sociedade civil para a realização de fins comuns. A grande, senão única, tarefa estatal consiste em propiciar, sob a égide de leis gerais, constantes e uniformes, condições de segurança - física e jurídica - à vida individual. Compete a cada indivíduo fixar suas finalidades de vida, no respeito às leis asseguradoras de uma convivência harmoniosa de escolhas individuais..$^{13}$

A mudança de paradigmas somente começa a ocorrer no século $X X$, com as constituições mexicana (1917) e de Weimar (1919). Nelas, passa-se a disciplinar 12 Vital Moreira, "O futuro da Constituição". In: GRAU, Eros Roberto \& GUERRA FILHO, Willis Santiago (org.): Direito Constitucional - estudos em homenagem a Paulo Bonavides. São Paulo: Malheiros Ed., 2001, pp. 314/315.

13 Fábio Konder Comparato. "Ensaio sobre o juízo de constitucionalidade de políticas públicas". Revista dos Tribunais, v. 737 (1997), pp. 11-22, p. 16. 
também a economia e o trabalho. A economia tornou-se também uma questão do Estado e, consequentemente, uma questão constitucional. E ao lado dos direitos e da liberdade individuais, entraram na Constituição os direitos coletivos e os direitos a prestações do Estado (direitos econômicos, sociais e culturais). Inicia-se a fase do constitucionalismo conformador da ordem econômica e social, por meio de regras e princípios orientadores da ação estatal, de programas de ação e políticas públicas.

O Estado deixa de ser o único elemento referencial da Constituição, que incorpora agora também a economia e a sociedade ${ }^{14}$.

Pois bem: a segunda revolução, ocorrida principalmente após a segunda guerra mundial, com a difusão das constituições rígidas, equivale a um completamento do Estado de Direito, ou seja, a sujeição ao ordenamento jurídico de todos os poderes, inclusive o legislativo, que também passa a se subordinar à Constituição, não mais apenas quanto às formas e ao processo de formação das leis, mas também quanto ao seu conteúdo. No Estado constitucional de direito, consequentemente, o legislador não mais é onipotente, no sentido que as leis que ele emana são válidas somente porque produzidas com observância das formas estabelecidas pelas normas sobre sua produção. Sua validade passa a ser condicionada também pela sua compatibilidade com os princípios constitucionais. E não é onipotente nem mesmo a política, cuja relação com o direito se inverte: também a política e a legislação, que é o seu produto, se subordinam ao Direito ${ }^{15}$.

Zagrebelsky ${ }^{16}$ explica que os princípios que contêm valores de justiça tornaramse direito positivo inserido na Constituição; portanto, o apelo à justiça ao lado ou contra as regras da lei não mais pode ser visto como um gesto subversivo ou destrutivo do Direito, sendo, ao contrário, um acontecimento previsto e admitido. Tais princípios consistem essencialmente em "noções de conteúdo variável" e, portanto, revelam uma função essencialmente dinâmica.

Pode-se dizer, com Cappelletti ${ }^{17}$, quea Constituição representa, no Direito moderno, uma forma legalista de superar o legalismo, um retorno ao jusnaturalismo com 14 Vital Moreira, op. cit., p. 315.

15 L. Ferrajoli, op. cit., p. 286-287.

16 Gustavo Zagrebelsky, I/ diritto mite, pp. 201/202.

17 Mauro Cappelletti, Il controllo giudiziario di costituzionalità delle leggi nel diritto comparato, pp. $122 / 123$. 
os instrumentos do positivismo jurídico. A norma constitucional, embora sendo norma positiva, conduz a uma aproximação do direito à justiça. Como norma naturalmente mais genérica, vaga, elástica, ela compreende aqueles conceitos de valor que postulam uma atuação acentuadamente criativa.

Exatamente por ser estruturada por normais de cunho mais principiológico e, portanto, de maior vagueza, as constituições exigem um profundo esforço hermenêutico para que corretamente delas se extraia um conteúdo de contornos mais definidos. $E$, pela divisão das funções entre os órgãos estatais, cabe ao Judiciário a última palavra em termos de interpretação constitucional. E isso acarreta, naturalmente, um grande poder. O bispo inglês Benjamin Hoadly, no seu "Sermon Preached Before King George I", há cerca de três séculos, já havia dito que "quem quer que tenha a autoridade absoluta para interpretar qualquer lei, é verdadeiramente o legislador, para todos os propósitos, e não a pessoa que originariamente a redigiu". E no célebre caso que inaugura, na Suprema Corte norte-americana, o controle de constitucionalidade (Marbury v. Madison, 1803), John Marshall afirmou que "it is emphatically the province and duty of the judicial department to say what the law is" (em tradução livre: é enfaticamente da competência e dever do poder judiciário dizer o que a lei é). Analisando as relações entre a Suprema Corte e o Presidente dos Estados Unidos, ao longo da história, Whittington ${ }^{18}$ refere que os presidentes cederam espaço aos justices. Eles se reservam o direito de reclamar e de tentar persuadir, mas eles não se atribuem o direito de dizer o que significa a Constituição.

Entende-se a mudança da posição do juiz relativamente à lei como produto deste novo paradigma. A sujeição à lei e, sobretudo, à Constituição, efetivamente transforma o juiz em garante dos direitos fundamentais também contra o legislador, através do reconhecimento judicial da invalidade das leis que violam aqueles direitos. Disto tudo deriva que a interpretação judiciária da lei é sempre também um juízo sobre a própria lei, relativamente à qual o juiz tem o dever de escolher somente os significados válidos, ou seja, compatíveis com as normas constitucionais substanciais e com os direitos fundamentais por estas estabelecidas ${ }^{19}$.

18 Keith E. Whittington, Political Foundations of Judicial Supremacy, p. 284. A citação do discurso do bispo Hoadly está destacada na quinta folha de seu livro, dedicada a citações.

19 L. Ferrajoli, "Giurisdizione e democrazia", Democrazia e Diritto, 1997, n. 1, p. 288. 
Outra característica das modernas constituições consiste na presença de instâncias voltadas ao futuro, que requerem uma atuação progressiva do Estado, num período dilatado de tempo, mediante a implementação de políticas públicas.

Nas palavras de Eros Grau, "Constituição dirigente que é, a de 1988 reclama e não apenas autoriza - interpretação dinâmica. Volta-se à transformação da sociedade (...)", por meio de políticas públicas que importam o fornecimento de prestações positivas à sociedade ${ }^{20}$.

Dentro dessa ideia de que o Estado contemporâneo, principalmente quando se tem em vista países em vias de desenvolvimento ou historicamente marcados por injustiças e desigualdades sociais, necessariamente está voltado a transformações, o Chefe de Estado ( $\mathrm{e}$, em forma diversa, também o juiz constitucional) não é apenas o garante daquilo que é, mas também daquilo que deve ser e, às vezes, daquilo que deve ser contra aquilo que é, como referiu G. Silvestri21. Na verdade, é possível se sustentar que qualquer agente estatal - portanto, também os juízes ordinários - deve ter por dever maior aquele de concretizar os mandamentos constitucionais no âmbito de sua atividade. Se esta concretização significa mudança, no sentido de se alcançar o horizonte traçado pela Constituição, então que seja.

No caso brasileiro, o impacto do moderno constitucionalismo foi ainda mais marcante que em outros países. A razão é dada por Barroso, ao referir que a Constituição de 88 disciplinou inúmeras matérias que antes eram deixadas para o processo político majoritário e a legislação ordinária:

A Carta brasileira é analítica, ambiciosa, desconfiada do legislador. Como intuitivo, constitucionalizar uma matéria significa transformar Política em Direito. Na medida em que uma questão — seja um direito individual, uma prestação estatal ou um fim público - é disciplinada em uma norma constitucional, ela se transforma, potencialmente, em uma pretensão jurídica, que pode ser formulada sob a forma de ação judicial. Por exemplo: se a Constituição assegura o direito de acesso ao ensino fundamental ou ao meio-ambiente equilibrado, é possível judicializar a exigência desses dois direitos, levando ao Judiciário o debate sobre ações concretas ou políticas públicas praticadas nessas duas áreas. ${ }^{22}$

20 Eros Roberto Grau. A ordem econômica na Constituição de 1988 (interpretação e crítica). 2a Ed. São Paulo: Revista dos Tribunais, 1991, p. 233/234.

21 Gaetano Silvestri, "Poteri attivi e poteri moderatori: attualità della distinzione", in: Lorenzo Luatti (org.), L'equilibrio tra i poteri nei moderni ordinamenti costituzionali, p. 32.

22 Luís Roberto Barroso, "Judicialização, ativismo judicial e legitimidade democrática", in http://www.con- 
Passa-se, agora, a abordar o item da nova organização do poder e como isso impactou o judiciário.

\subsection{A nova organização do poder}

O Estado-monolito da era napoleônica, cujo governo central tinha o monopólio exclusivo da representação de todos os interesses públicos, nada mais é atualmente do que uma recordação histórica. No lugar desta administração compacta, hierarquizada, quase militar, que fora típica do início do Estado contemporâneo, agora se descobriu um espaço político ocupado por uma multidão de sujeitos institucionais autônomos ou semiautônomos, por vezes conflitantes entre si. É o mundo das autarquias, empresas públicas, fundações, agências reguladoras dotadas de elevada autonomia, comissões independentes, etc.

Em um mundo político caracterizado por um crescente pluralismo institucional, a atividade governamental mostra-se cada vez mais como um esforço de composição entre interesses divergentes do que como a realização autoritária de uma vontade central. Em suma, em toda sociedade complexa e policêntrica, o poder público é, antes de tudo, poder de mediação ${ }^{23}$.

Nesse contexto, a expansão do poder judiciário é apenas um elemento de um fenômeno mais geral, ou seja, a expansão de todos os ramos do governo nos estados contemporâneos. O aumento do papel do legislador e do poder executivo justifica - e até mesmo exige - um aumento correspondente do poder judiciário, caso se pretenda que os poderes do estado permaneçam equilibrados. Esta é uma exigência da qual não se pode escapar, num sistema que preconiza que o exercício de um poder seja limitado pela ação de um outro, de modo a manter-se o equilíbrio. Ao agigantamento dos demais poderes, portanto, deve corresponder o agigantamento do Judiciário, senão em tamanho, ao menos certamente em importância e funções.

Assim, um controle jurisdicional sobre as ações dos demais poderes é essencial para assegurar a supremacia do direito: para que o Estado seja um Estado de direito (Rechtstaat) e para que o direito possa imperar (rule of law) ${ }^{24}$.

jur.com.br/2008-dez-22/judicializacao_ativismo_legitimidade_democratica.

23 Nesse sentido, Luca Mannori, "Giustizia e amministrazione tra antico e nuovo regime", in: Raffaele Romanelli (Org.). Magistrati e potere nella storia europea, pp. 64 e 65.

24 M. Cappelletti, "Un probleme majeur: controle juridictionnel des lois et principe de democratie. Etude de 


\subsection{A crise do Poder Legislativo}

Na condição de relator geral do seminário sobre "Novas perspectivas para um direito comum europeu", realizado em Florença, em meados da década de setenta, Mauro Cappelletti referiu a existência de certo consenso entre os diversos relatores nacionais daquele conclave: a de que as necessidades das sociedades contemporâneas não estavam sendo suficiente e eficientemente satisfeitas pelos legislativos nacionais. A sobrecarga de demanda normativa tornava o legislador lento e sem condições de responder com rapidez às necessidades sociais. E concluía: "Deriva disso que um maior ativismo judicial isto é, a criação ou adaptação do direito através do juiz - é uma característica comum a todos os países ocidentais" ${ }^{\prime 25}$.

De fato, vem sendo percebido, há várias décadas e de forma persistente, que - legislador não vem sabendo desempenhar suas clássicas funções com a eficácia necessária. O envelhecimento das leis frente a uma sociedade em rápida transformação e a falta de regulamentação, por parte dos órgãos legislativos, de novos fenômenos que envolvem amplos interesses sociais, contribuíram para deslocar para o judiciário a solução de problemas e de incertezas que deveriam encontrar uma resposta na intervenção legislativa.

Em outras situações, a intervenção legislativa apresenta-se parcial e descontínua, dando ao juiz mais uma vez a ocasião e a necessidade de recorrer a uma obra de interpretação criativa ou, pelo menos, integrativa ${ }^{26}$.

Danilo Zolo ${ }^{27}$ indica alguns sinais de tensões presentes nas sociedades industriais avançadas:

1. Autores como Luhmann, Scharpf e Teubner denunciam a crise do "subsistema jurídico" em termos de sobrecarga legislativa e de crescente incoerência do ordenamento jurídico. A complexidade e a variabilidade das situações administrativas fazem com que a produção normativa, não obstante a sua

droit comparé". In : Le pouvoir des juges, p. 241 e 242.

25 M. Cappelletti (Org.). New Perspectives for a Common Law of Europe. "Introduction". Firenze: Le Monnier, 1978, p.16. Há que se esclarecer, porém, que apesar de todos os analistas praticamente concordarem com a presença e atuação desse poder criativo dos juízes, remanesce forte corrente crítica de tal fenômeno. Por todos, veja-se François Terré, "Un juge créateur de droit? Non merci !", in : La création du droit par le juge, volume especial (tome 50), de Archives de philosophie du droit, p. 305-311.

26 Nicolò Trocker, "La responsabilità del giudice", R.T.D.P.C., 1982, p. 1292.

27 Danilo Zolo, "Cittadinanza democratica e giurisdizione", in: Nello Rossi (Org.). Giudici e democrazia. La magistratura progressista nel mutamento istituzionale, pp., 86/88. 
quantidade aluvial, esteja constantemente em atraso relativamente à evolução dos temas a administrar.

2. O legislador é cada vez menos soberano: soberanos são os milhares de sujeitos que "têm o poder de interpretar", e este poder é sempre, em grande medida, um poder extra ou contra legem.

3. Antigamente os Parlamentos nacionais eram os titulares únicos da produção normativa. Hoje a função legislativa parece pertencer a certos sujeitos que operam em uma situação de quase invisibilidade. Ao lado da crescente atividade normativa dos governos, a identificação das fontes tornou-se mais difícil em virtude da extensa influência de organismos internacionais, das fontes normativas locais, do próprio poder crescente dos intérpretes em sede judiciária.

Efetivamente, o legislador está empenhado em uma corrida febril contra o relógio. A máquina legislativa é pesada; frequentemente é demasiadamente lenta para satisfazer tempestivamente as novas e urgentes necessidades da sociedade. Além disso, muitas vezes tais necessidades não são suscetíveis de solução abstrata, genérica e permanente, qualidades estas que usualmente caracterizam a resposta legislativa. Esta situação de impasse faz com que aumentem as funções judiciárias.

Segundo Cappelletti2 ${ }^{28}$, em um tal contexto deve o juiz dar sua contribuição para a resolução dos novos problemas surgidos na sociedade, procedendo a uma interpretação evolutiva, dinâmica e criativa da legislação, tendo por guia as linhas do projeto constitucional.

O descompasso entre as prementes e cambiantes necessidades sociais e a tardia resposta legislativa faz com que acabe sendo o juiz o atualizador preferencial do direito.

De fato, nas palavras de José Puig Brutau:

Os fatos e as circunstâncias, que as normas se destinam a regular, evoluem com uma rapidez superior à marcha que se possa imprimir ao Direito codificado pela atividade legislativa. O legislador pode, certamente, adiantar-se muito mais com um só de seus passos do que os juízes com todo o seu acervo acumulado de decisões ou sentenças; mas os períodos de inatividade, de inércia ou de irresolução dos Parlamentos não lhes permitem, a estes, com a assiduidade requerida,

28 M. Cappelletti, “Liberté individuelle et justice sociale dans le procès civil italien”, Rev. int. dr. comp., v. 23, 1971, p. 551. 
assinalar novos rumos à evolução jurídica, ante o incessante progresso representado pela atividade diária dos profissionais do direito e, sobretudo, dos juízes. O legislador se assemelha, assim, a um míope privilegiado com uma arma poderosa ${ }^{29}$.

Certamente existe hoje uma maior responsabilidade dos juízes na formatação do Direito, desconhecida dos ordenamentos anteriores. Eles são os garantes da complexidade estrutural do Direito no moderno Estado constitucional, isto é, da necessária e branda coexistência de leis, Direito e justiça. O direito não é objeto de propriedade de ninguém, devendo, ao contrário, ser objeto de atenção e cuidado de muitos ${ }^{30}$. Também Castanheira Neves chama a atenção para a circunstância de que o direito não é algo dado, mas construído, que suscita a responsabilidade do jurista. Segundo o mestre lusitano, cumpre ao jurista "assumir e realizar a idéia de direito - sendo certo que o direito não é um "dado" que o jurista tenha de receber, é uma tarefa que o concita a um esforço e a uma responsabilidade"31.

Daí por que vem sendo entendido que "incumbe essencialmente ao aplicador do direito - e não ao legislador - encontrar as primeiras respostas para os novos problemas sociais", devendo, para tanto, "olhar para o futuro e trilhar caminhos ainda não demarcados", bem como deve o juiz "ter a coragem de enfrentar a opinião dominante, ao invés de se resignar a seguir a jurisprudência estabelecida", afastandose, se for o caso, de determinados consensos, pois muitas vezes "falsas unanimidades não passam de preconceitos coletivos, fruto dos argumentos de autoridade"32.

Discorrendo sobre o caso brasileiro, especialmente sobre o Supremo Tribunal Federal, o Ministro Barroso recentemente assim se pronunciou:

Diversos fatores contribuem para o excesso de exposição e visibilidade do Supremo Tribunal Federal. (...) Dois fatores conjunturais estão diretamente ligados ao Poder Legislativo. O primeiro envolve uma certa dificuldade de o Congresso legislar sobre temas importantes e divisivos, como desaposentação, terceirização ou greve no setor público. Isso obriga o Tribunal a decidir as questões que lhe são submetidas tendo de produzir as normas faltantes. Portanto, acaba desempenhando uma função legislativa por falta de opção. ${ }^{33}$

29 José Puig Brutau, A jurisprudência como fonte do direito, p. 21.

30 G. Zagrebelsky, II diritto mite, p. 213.

31 A. Castanheira Neves, na conferência "O papel do jurista no nosso tempo", inserido no DIGESTA - Escritos acerca do direito, do pensamento jurídico, da sua metodologia e outros p. 32.

32 Inocêncio Mártires Coelho. Interpretação Constitucional, p. 49.

33 Luis Roberto Barroso, "O Supremo Tribunal Federal em 2016: o ano que custou a acabar", disponível 
Ao serem forçados a decidir alguns casos que não encontraram solução na seara legislativa, os juízes, nos chamados casos difíceis (hard cases), em que não há consensos possíveis por envolverem temas que dividem a sociedade, acabam fatalmente se lançando no centro de debates acalorados, sendo destinatário de críticas severas pela parte da população que discorda do que foi decidido. É o caso das decisões do Supremo Tribunal de Justiça (ADI 4277 e ADPF 132, em 2011), e da Supreme Court norte-americana (caso Obergefell v. Hodges, 2015), ao decidirem favoravelmente às uniões estáveis (Brasil) ou ao casamento (EUA) entre pessoas do mesmo sexo, a desta última corte no caso que pôs fim ao regime de segregação racial nas escolas norte-americanas (caso Brown v. Board of Education of Topeka, 1954), e a que considerou inconstitucional certas leis que proibiam o aborto voluntário (caso Roe v. Wade, 1973), bem como os casos envolvendo a liberação do aborto e a proibição de crucifixos em salas de aula de escolas públicas, na Alemanha ${ }^{34}$, dentre inúmeras outras decisões que dividiram a sociedade.

\subsection{A crise da legislação e suas novas características}

Houve um tempo em que se imaginava ser possível a criação de leis tão completas, coerentes e claras a ponto de tornar supérflua a própria interpretação. O abandono de tal dogma da infalibilidade legislativa foi lento e trabalhoso.

Segundo o pensamento rousseauniano, o poder legislativo "pertence ao povo e não pode pertencer senão a ele" 35 . Sendo a lei expressão da vontade geral, manifestada diretamente pelo povo reunido em assembleia, necessariamente é ela ditada no interesse de todo o povo, segundo tal concepção.

Discorrendo sobre tais passagens do Contrato Social, Barzotto refere o que seria característica essencial da legislação, dentro de sua noção clássica, afirmando que "a lei não pode pronunciar-se sobre este ou aquele fato, este ou aquele cidadão. A abstração e a generalidade pertencem a ela por definição"36. Ora:

em http://www.migalhas.com.br/arquivos/2017/1/art20170109-01.pdf. Acesso em: 28.01.2017.

34 Sobre os casos alemães, v. Tim Koopmans, Courts and Political Institutions - A Comparative View, p. 69.

35 Jean-Jacques Rousseau. Do contrato social, Livro III, cap. I, p. 74 (87).

36 Luis Fernando Barzotto, A democracia na Constituição, p. 114. 
Na estrutura do Estado Dirigente, a lei perde asua majestade de expressão por excelência da soberania popular, para se tornar mero instrumento de governo. A grande maioria das leis insere-se, hoje, no quadro de políticas governamentais, e têm por função não mais a declaração de direitos e deveres em situações jurídicas permanentes, mas a solução de questões de conjuntura, ou então o direcionamento, por meio de incentivos ou desincentivos, das atividades privadas, sobretudo no âmbito empresarial, ou ainda a regulação de procedimentos no campo administrativo. A tendência geral, de resto, em todos os países, vai no sentido do alargamento da competência normativa do governo, não só na instância central, através de decretos-leis ou medidas provisórias, mas também no plano inferior das chamadas organizações administrativas autônomas, de que são modelo consagrado as independent regulatory commissions dos Estados Unidos ${ }^{37}$.

Face à crise regulatória do Estado e diante da carência de representatividade dos órgãos legiferantes, a lei arrisca tornar-se um mero instrumento de legitimação de uma ou mais políticas públicas, de conveniências parciais e de nem sempre claros equilíbrios, provisoriamente atingidos entre as partes interessadas. Tratase de um retorno ao velho brocardo "Auctoritas, non veritas facit legem", de forma que se instaura um sistema, no qual por um lado é a auctoritas que legitima a lex, enquanto de outro lado se recorre à lex para legitimar a auctoritas. Significa mover-se em um perfeito círculo vicioso ${ }^{38}$.

Dos códigos liberais se esperava que tutelassem a propriedade, os contratos, a família, de acordo com uma coerente ideologia liberal burguesa, o que propiciava a manutenção da unidade sistemática de todo o sistema. O problema é que, com a descodificação, toda essa coerência sistemática foi varrida. A legislação, fruto de acordos setoriais, não mais expressa uma única visão ideológica, mas uma pluralidade de visões. Neste contexto, a atividade do juiz se torna muito mais difícil e, contemporaneamente, mais necessária. Mais difícil porque o juiz não mais dispõe de uma trilha bem visível para encontrar o caminho justo. Mais necessária, porque cabe a ele conferir um pouco de organicidade, sistematicidade e coerência a este conjunto de fontes jurídicas. Isto pode ser feito atribuindo-se aos valores constitucionais o poder de amálgama, já que são eles os únicos que

37 Fábio K. Comparato, "Ensaio ...", cit., p. 19.

38 Giulio M. Chiodi, "Giurisdizione ed equità regolativa", in: E. Bruti Liberati, A. Ceretti e A. Giasanti (org.), Governo dei giudici. La magistratura tra diritto e politica, p. 37. 
atualmente podem conferir certa unidade à legislação.

Segundo Judith Martins-Costa:

(...) o legislador reconhece que é impotente para apreender, previamente, a totalidade das situações de vida merecedoras de tutela jurídica. Por isto, em determinadas situações, notadamente aquelas em que os padrões sociais não estão firmemente assentados, ou não podem ser assentados senão de forma provisória, como ocorre com os padrões técnicos e científicos, limita-se o legislador a conferir, mediante o modelo aberto, uma espécie de 'mandado' para que o juiz possa, progressivamente, e à vista da alteração nos paradigmas sociais, culturais, científicos, éticos, etc., regular os casos concretos, criando, complementando ou desenvolvendo aquelas normas postas como 'programas', isto é, indicações de fins a perseguir ou de valores a garantir ${ }^{39}$.

Assim, cada vez mais o legislador opta por modelos legislativos mais abertos, usando, ao lado das tradicionais regras precisas e detalhadas, princípios, cláusulas gerais, conceitos indeterminados, diretrizes. Isso necessariamente fornece ao intérprete-juiz uma maior margem de liberdade hermenêutica. É o que se observa, também, nos projetos de uniformização do direito contratual, em nível internacional ou europeu, como informam Diurni e Henrich ${ }^{40}$.

Ainda nos casos em que não esteja presente, de forma direta, uma questão constitucional, o texto constitucional continuará sendo uma fonte potencial de influência sobre a interpretação dos textos jurídicos. Quando uma escolha entre diversas possibilidades interpretativas é necessária, deverá ser preferida aquela que seja mais consistente com o ditado constitucional ${ }^{41}$.

Diante deste fenômeno do enfraquecimento da lei, G. Chiodi² pensa ser conveniente insistir sobre a distinção entre direito e lei, recordando Leibniz, para quem a lei pode ser injusta, enquanto o direito não pode e não deve sê-lo jamais. A lei tem sempre algo a ver com a politicidade, pois nasce sempre como fruto de uma decisão de alguém. A lei não pode prescindir de escolhas políticas. $O$ Direito, como ordenamento social, ao contrário, estabelece regras que podem 39 Judith Martins-Costa, "Bioética e Dignidade da Pessoa Humana: Rumo à Construção do Biodireito", in: Revista fa Faculdade de Direito da UFRGS, v. 18 (2000), p. 156, nota de rodapé n. 9.

40 Amalia Diurni \& Dieter Henrich, Percorsi europei di diritto privato e comparato, p. 19.

41 Sobre o tema, vide John Henry Merryman, "How Others Do It: the French and German Judiciaries", 61 S. Cal. L. Rev. 1988, pp. 1868, 1869 e 1872.

42 Giulio M. Chiodi, "Giurisdizione ..., cit., p. 43. 
prescindir de uma escolha política e que não podem trair instâncias morais, ainda que mutáveis no espaço e no tempo.

\subsection{O welfare state e seu reflexo na função jurisdicional}

Derrubados, com a teórica proclamação da igualdade política de todos os cidadãos, os obstáculos jurídicos que, sob o ancien régime, reservavam a restritas categorias sociais a participação no governo da coisa pública, a liberdade encontrou os seus obstáculos não mais no plano político, mas no plano econômico: e daquele a este se deslocou a luta pela liberdade. (Piero Calamandrei).

Estas palavras de Calamandrei ${ }^{43}$ explicam o porquê do advento do welfare state, que, no segundo pós-guerra, fez incluir nas novas constituições, ao lado dos tradicionais direitos individuais, um novo elenco de "direitos sociais". A função destes novos direitos é essencialmente aquela de garantir a cada um aquele mínimo de justiça social, ou seja, de bem-estar econômico, que parece indispensável para libertar os marginalizados da escravidão das necessidades ${ }^{44}$. Isto porque a liberdade proclamada abstratamente pouco significa, pois ela somente se converte em possibilidade real na medida em que os indivíduos dispõem das condições necessárias que permitem a autodeterminação.

Efetivamente, às consolidadas funções de regulação e de coerção, apresenta-se cada vez mais claramente uma função distributiva do direito, chamado a atribuir bens, oportunidades e recursos entre os consociados, incidindo sobre a maneira e a qualidade de seu viver ${ }^{45}$.

A filosofia política do Estado social traduziu-se no crescimento da legislação socioeconômica, correspondente às intervenções do Estado em setores cada vez mais numerosos, até então largamente deixados à iniciativa e à autonomia privada: trabalho, produção, comércio, educação, habitação, saneamento, consumo, meio ambiente, etc. As tarefas do Estado social ampliaram-se enormemente. À função tradicional de mera proteção e repressão de violações dos direitos individuais

43 Piero Calamandrei, "L’avvenire dei diritti di libertà", introduzione a F. Ruffini, Diritti di libertà, p. XXII.

44 P. Calamandrei, ult. op. cit., p. XXVII. Como referiu Lord Leslie Scarman: "Todos nós temos o direito de receber a proteção ativa do Estado contra os males da pobreza, da doença e da velhice. A justa distribuição de riqueza entre todos os membros da sociedade tornou-se um direito humano tão importante para o Direito como o direito à propriedade" (O direito inglês. A nova dimensão, p. 41).

45 Anna De Vita, vocábulo "Diritto alla casa in diritto comparato", nel DIGESTo, Disc. Priv., Sez. Civ., t. VI, p. 35. 
tradicionais - o Estado como mero 'gendarme' ou 'night watchman' da filosofia política do laissez-faire -, foram acrescidas tarefas de promoção e de atuação dos novos direitos sociais, os quais tipicamente comportam um empenho de fazer, operar, intervir, da parte do Estado ${ }^{46}$.

Todavia, alerta Cappelletti ${ }^{47}$, que a estrutura dos novos direitos sociais é radicalmente diversa da estrutura das liberdades tradicionais. Diversamente de quanto ocorre com os direitos individuais de liberdade, não basta a afirmação dos direitos sociais em uma determinada norma constitucional para que esses, automaticamente, encontrem um correspondente reflexo na realidade jurídica do Estado: eles não acarretam, para o Estado, como acontece com as liberdades políticas, um mero dever negativo de não fazer, de deixar fazer, mas sim uma obrigação positiva de agir, - uma obrigação, além disso, que tem o caráter de permanência, que tem a necessidade de ser adimplida em caráter contínuo, porque não é daquelas que se cumprem e se exaurem uma vez para sempre.

Discorrendo sobre a situação dos países desenvolvidos, diz Livio Pepino ${ }^{48}$ que, na "sociedade dos dois terços", na qual quem necessita de ajuda e sustento é minoria (ainda que consistente), os direitos sociais frequentemente se encontram em contraste com os interesses da maioria. Isto coloca em primeiro plano a jurisdição (principalmente a civil) em função de tutela e de promoção dos direitos sociais da cidadania.

De fato, a época contemporânea é caracterizada por uma crescente expansão de direitos que, pela sua própria natureza, são destinados a encontrar no juiz o seu garante institucional. A judicialização da vida social é, em suma, uma tendência que se encontra em todos os ordenamentos ${ }^{49}$.

\subsection{A crise do welfare state}

Se o advento do Estado social dilata as funções da jurisdição, a sua crise pode concorrer para acentuar ainda mais tal ampliação. Segundo Campilongo, quanto maior a crise econômica, maiores as demandas de expansão de direitos sociais.

46 M. Cappelletti, "Accesso alla giustizia come programma di riforma e come metodo di pensiero", Riv. dir. proc., 1982, p. 237/238.

47 M. Cappelletti, "I diritti sociali di libertà nella concezione di Piero Calamandrei", in: Processo e ideologie, p. 517.

48 Livio Pepino, "Compiti della politica, doveri della giurisdizione", Questione giustizia, n. 4, 1995, p. 773.

49 Vittorio Denti, "I procedimenti non giudiziali di conciliazione come istituzioni alternative", Riv. dir. proc., 1980, p. 433. 
Estabilidade no trabalho, seguro desemprego, serviços públicos de transporte, saúde e educação, por exemplo, são reivindicados com grande intensidade exatamente nos momentos de estagnação da economia ${ }^{50}$.

Importante reproduzir a seguinte passagem do Ricardo Lorenzetti sobre as consequências, inclusive no âmbito jurídico, da crise do welfare state. Diz o autor argentino, aludindo a um fenômeno de feudalização do direito, que:

É interessante observar o comportamento de um indivíduo minimamente auto-suficiente frente ao Estado: os hipossuficientes sempre irão dele depender. Quando existia o 'Estado do Bem-Estar', sua função era a de redistribuir riqueza. Todos os atores sociais queriam estar vinculados ao Estado porque de uma maneira ou de outra obtinham algum benefício. $O$ comportamento racional era o de vincular-se ao Estado.A função do Estado, de acordo com o modelo atual, é repartir custos, adjudicar ônus. (...)Nesse contexto, o comportamento racional dos indivíduos auto-suficientes é o de não se vincular ao Estado. As classes alta e média vivem em condomínios onde o município tem pouco o que fazer. A polícia é substituída por vigilância contratada; a escola pública, pela privada; o sistema de saúde, pelos planos de assistência médica pré-contratada; o crédito estatal, pelo crédito privado. Assistimos, ultimamente, a pior das deformações; a justiça estatal é substituída pela justiça privada, as pessoas se armam e se defendem por si mesmas ou contratam policiais privados.Esse indivíduo não necessita do Estado; pretende que seja suprimido, porque ele está satisfeito, não tem necessidade da ação pública. O Estado incomoda-o, cobra-lhe impostos, a lei impõe-lhe ônus, responsabilidades: é preciso reduzi-lo ao mínimo.Não necessita do Estado porque tem seu próprio feudo, e por isso dizemos que estamos assistindo a uma nova Idade Média ${ }^{51}$.

Portanto, mais uma vez se constata que a maior ou menor função do Poder Judiciário está não só ligada à concepção estrutural do Estado, como também à organização econômica da sociedade.

\subsection{O problema do controle do poder}

Segundo Bobbio ${ }^{52}$, o problema fundamental do Estado constitucional moderno diz respeito aos limites do poder estatal, pois grande parte das teorias elaboradas ao longo dos séculos está inspirada em uma ideia fundamental: a de estabelecer

50 Celso Fernandes Campilongo. Direito e Democracia, p. 84/85.

51 Ricardo Luis Lorenzetti. Fundamentos do direito privado [Las normas fundamentales de derecho privado, pp. 54/55.

52 Norberto Bobbio. Direito e Estado no Pensamento de Emanuel Kant (Diritto e Stato nel Pensiero di Emanuele Kant), p. 11. 
limites ao poder do Estado. Tais limites ou estavam vinculados à teoria dos direitos naturais, conhecida desde a antiguidade, ou à da separação dos poderes, desenvolvida no século XVIII, ou às teorias da soberania popular.

A ideia da separação dos poderes enriqueceu-se e complicou-se com o ingresso, na cena político-constitucional, de novos sujeitos (pense-se nas agências reguladoras, nos "garantes" do direito italiano, no "defensor del pueblo", além de figuras mais antigas, como o 'ombudsman' escandinavo), os quais detêm funções próprias, além de novas configurações que outros sujeitos institucionais adquiriram (como o Chefe de Estado, nos regimes parlamentares, as Cortes Constitucionais europeias, os Tribunais de Conta, etc.). As constituições modernas, por outro lado, tentam promover uma situação de equilíbrio entre órgãos primários do Estado mediante a previsão de recíprocas interferências: ou seja, uma situação em que nenhum dos diversos poderes ou órgãos constitucionais competentes para assegurar o equilíbrio possa prevalecer sobre os outros de forma absoluta ${ }^{53}$.

Mais realista parece ser a visão de M. Cappelletti ${ }^{4}$, ao opor a doutrina francesa da separation des pouvoirs à doutrina americana dos checks and balances. Realmente, enquanto a primeira foi interpretada e aplicada no sentido de vetar qualquer possibilidade de interferência dos juízes na esfera dos outros poderes, a segunda foi inspirada no recíproco controle e equilíbrio entre os poderes do Estado. À luz desta concepção, explica-se perfeitamente, por um lado, como o poder judiciário possa controlar, nos Estados Unidos, a constitucionalidade das leis - e também a legalidade dos atos administrativos -; e, por outro lado, como os poderes legislativo e executivo possam intervir, por sua vez, no momento da escolha e da nomeação dos juízes.

Entendendo-se que o juiz exerce suas funções, como diz o art. 101 da Constituição italiana, diretamente 'em nome do povo', pode-se identificar no poder judiciário, relativamente aos demais poderes do Estado, um verdadeiro contrapoder, no duplo sentido de lhe ser atribuído o controle de legalidade, ou seja, de validade dos atos legislativos, assim como dos atos administrativos, bem como a tutela

53 Federico Sorrentino, "L'equilibrio istituzionale fra i poteri e la sua garanzia giurisdizionale", in: Lorenzo Luatti (org.), L'equilibrio tra i poteri nei moderni ordinamenti costituzionali, p. 62.

54 M. Cappelletti, Il controllo giudiziario di costituzionalità delle leggi nel diritto comparato, p. 85. 
dos direitos fundamentais dos cidadãos em face do Estado. E esta função pode ser exercida pelo poder judiciário exatamente por que ele não é representativo, mas sujeito somente à lei e obrigado ao "accertamento" da verdade, quaisquer que sejam os sujeitos julgados e os contingentes interesses em jogo. Neste sentido, a função judiciária é uma 'garantia' de todos os cidadãos contra o próprio governo representativo ${ }^{55}$.

Problema agudo e permanente em praticamente todas as sociedades, em todas as épocas, é aquele da corrupção. Trata-se de um fenômeno que parece ser inerente ao exercício do poder político. Se não existem barreiras, tende a espraiar-se e a permear todas as relações sociais, enfraquecendo gravemente a democracia.

Todavia, ainda quando a corrupção se alastra, permanece sempre na sociedade um grande número de cidadãos não corruptos e não corruptíveis. Portanto, somente um poder difuso, fracionado, não centralizado, pode subtrair-se à corrupção e contrastá-la. Assim, é essencial que a repressão aos crimes de corrupção seja atribuída a sujeitos que não integram um poder concentrado ${ }^{56}$.

De qualquer sorte, não só questões envolvendo corrupção exigem do Judiciário uma tomada de posição. Praticamente todas as Cortes Supremas dos países democráticos frequentemente são acionadas para dirimir conflitos que diretamente afetam e limitam a atuação dos demais poderes políticos. No Brasil, por exemplo, nos últimos anos, tornam-se cada vez mais frequentes os casos de decisões do STF que diretamente afetam os poderes do Legislativo (citemse os exemplos recentes da fixação, pelo STF, do roteiro a seguir no caso de impeachment da ex-Presidente Dilma Roussef) e do Executivo (como a suspensão da posse do ex-Presidente Lula para o Ministério de Dilma, também por liminar do STF). Em caso recentíssimo, até mesmo o conservador Judiciário britânico, em janeiro desse ano (2017), em demanda movida por dois cidadãos (um deles brasileiro, residente em Londres há dez anos), impediu a Primeira-Ministra de prosseguir nas tratativas da retirada da Inglaterra da União Europeia (Brexit), sem a participação do Parlamento britânico.

55 L. Ferrajoli, Diritto e ragione. Teoria del garantismo penale, p. 593/594.

56 Nesse sentido manifesta-se Elena Paciotti, ex-presidente da Associação Nacional dos Magistrados italianos, in "Ruolo della magistratura in uno stato democratico", Questione giustizia, n. 2-3., 1994, p. 370. 


\subsection{A função promocional do novo direito}

Classicamente se atribuíam ao direito fundamentalmente duas funções: protetiva (dos atos lícitos) e represssiva (dos atos ilícitos), desempenhadas por meio da emanação de comandos negativos (proibições). Nesta visão, típica do estado liberal clássico, atribuía-se ao Estado uma função de simples responsável pela manutenção da ordem pública. Apesar das tarefas do Estado terem aumentado enormemente, com o advento do Estado assistencial, muitas das teorias jurídicas contemporâneas ainda permanecem ancoradas a uma concepção redutiva do direito como simples ordenamento protetivo-repressivo.

Todavia, ao lado desse, toma forma uma nova imagem: aquela de um ordenamento jurídico com função promocional ${ }^{57}$. Esta nova função utiliza a técnica do encorajamento, buscando tornar particularmente atrativos os atos obrigatórios. Como explica Bobbio, ao ordenamento protetivo-repressivo "interessa sobretudo os comportamentos socialmente não desejados, e por isso o seu fim precípuo é o de impedir o quanto possível a sua realização". Já quanto ao ordenamento promocional "interessa sobretudo os comportamentos socialmente desejados, sendo seu objetivo o de provocar a efetivação prática dos mesmos" ${ }^{58}$.

De fato, hoje, mais do que nunca, o Direito possui uma função diretiva da mudança social $^{59}$. E esta função pode ser desempenhada por todos aqueles que pensam ser sempre possível a melhoria das relações sociais. E no caso do Judiciário, que integra o Estado, não se trata somente de um poder, mas mais exatamente um dever de concorrer, com o exercício das suas próprias funções, para aquela atividade de mudança social que as novas constituições, com o seu caráter promocional, impõem como uma das metas a atingir. Efetivamente, como afirma Senese ${ }^{60}$, "a função promocional envolve cada vez mais o juiz na aplicação da legislação". E quanto mais amplas são estas metas a atingir, quanto mais elástica é a legislação que as estabelece, tanto mais criativa é a atividade interpretativa do juiz, destinada à sua implementação.

Nesse contexto, a tarefa de promover a justiça não se limita a evitar que os

57 N. Bobbio, "Sulla funzione promozionale del diritto", R.T.D.P.C., 1969, p. 1322/1323.

58 N. Bobbio, op. ult. cit., p. 1324/1325.

59 Guido Alpa, L'arte di giudicare, p. 108.

60 Salvatore Senese, "Democrazia, sovranità popolare e giurisdizione", Questione giustizia, n. 2, 1987, p. 444. No mesmo sentido, M. Cappelletti, op. ult. cit. pp. 15 e 16. 
órgãos estatais façam alguma coisa de errado, mas abrange também a tentativa de garantir que eles cumpram corretamente o seu dever.

Aplicando a metodologia da análise econômica do direito aplicada à atividade jurisdicional, Richard Posner se preocupa com o impacto que a implementação da função promocional do direito (ainda que essa expressão não venha por ele utilizada), por meio do poder judiciário, pode haver no sistema. O seu raciocínio é no sentido que, mantendo-se constante a "oferta" de prestação jurisdicional (considerando-se que normalmente os sistemas judiciários funcionam em sua plena capacidade operativa), o aumento da "demanda" de serviços jurisdicionais destinados à implementação dos novos direitos acarretará fatalmente uma diminuição da eficiência relativamente à proteção e à implementação dos "antigos" direitos $^{61}$. Ainda que haja um fundo de verdade nessa intuição, pensa-se, porém, que isto não deve ser um obstáculo seja à criação de novos direitos, seja à utilização do aparato judiciário para a sua implementação. Porém a sua observação é válida no sentido de que se deve também cuidar da expansão da "oferta" dos serviços judiciários, os quais, em um ordenamento promocional, podem e devem tornar-se um elemento chave para a implementação dos novos direitos.

\subsection{A idéia de democracia participativa. 0 papel do judiciário}

"O problema da democracia não é o problema do governo mais eficiente; outros regimes podem ser mais eficientes. É o problema de um governo que garanta a máxima liberdade individual possível"62. Essa liberdade, aduz Barzotto, "é maximizada quando as regras que distribuem o poder político em uma sociedade possibilitam que o indivíduo submetido à ordem social participe no processo de sua criação"63.

Há muito tempo já foi acentuado o aspecto participativo das ações coletivas, dos indivíduos ou dos grupos, como momento de antagonismo, relativamente às escolhas do poder político e econômico. A via judiciária terminou por representar um dos instrumentos privilegiados desta conflitualidade participativa, seja pela sua genérica acessibilidade, comparativamente às formas de participação

61 Richard Posner, The Federal Courts, cit, pp. 316 e 317.

62 Hans Kelsen, "Fundamentos da democracia" (Trad. Jefferson L. Camargo e Marcelo B. Cippola). In: KELSEN, H. A democracia, p. 191.

63 L. F. Barzotto. A Democracia na Constituição, p. 132. 
administrativa, seja pelo papel de suplência que o poder judiciário repetidamente assumiu, na inércia dos demais poderes do Estado ${ }^{64}$.

A democracia participativa distingue-se tanto da democracia direta quanto da representativa. A distinção desta última é fácil, uma vez que essa se realiza por meio de institutos de tipo eleitoral, na qual o poder do cidadão resumese praticamente à escolha de seus representantes junto ao poder público. A característica principal da atividade participativa, ao contrário, é a própria intervenção dos cidadãos, individual ou organizadamente, nos procedimentos de tomada de decisões político-administrativas ${ }^{65}$.

A 'sede de direitos' individuais e coletivos, alimentada não somente pelo constitucionalismo liberal, mas também pelo estado social, orienta-se com cada vez maior frequência aos tribunais, para ali tentar fazer valer pretensões que não obtiveram respostas em outras sedes institucionais. A ida ao Judiciário, em tais circunstâncias, pode representar um instrumento de participação no processo político. Desde que tenham intenção de assumir tal tarefa, os tribunais poderão ser utilizados como autênticos canais de articulação de pretensões políticas (no sentido grego de politikon, relativo à polis, à cidade, àquilo que a todos concerne), ao lado dos canais institucionais clássicos e não raramente em competição com estes.

Vale a pena recordar que os tribunais oferecem relevantes vantagens aos seus potenciais usuários: em princípio são mais abertos do que as outras instituições políticas, na medida que os indivíduos não precisam dispor de recursos estratégicos para obter-lhe o acesso; não podendo 'denegar justiça', devem os juízes, de qualquer forma, fornecer uma resposta às demandas que lhe são dirigidas; finalmente são muito articulados territorialmente, e por isso mesmo mais acessíveis, uma vez que o Judiciário é um poder muito mais difuso do que os demais ${ }^{66}$.

Saliente-se que a ideia de democracia participativa, derivada da afirmação do pluralismo institucional, não se configura como uma alternativa à democracia representativa, mas sim a um enriquecimento desta.

64 Vittorio Denti, “I procedimenti non giudiziali...", cit., p. 435.

65 A. Pizzorusso, "Democrazia partecipativa e attività giurisdizionale", in Studi in onore di Giorgio Balladore Pallieri, v. I, p. 466.

66 Carlo Guarnieri e Patrizia Pederzoli, La democrazia giudiziaria, p. 17. 
No caso brasileiro, a ação popular constitui exemplo emblemático de exercício de uma democracia participativa. Por meio dela se confere legitimidade a qualquer cidadão para pleitear "a anulação ou a declaração de nulidade de atos lesivos ao patrimônio da União, do Distrito Federal, dos Estados, dos Municípios, de entidades autárquicas, de sociedades de economia mista", além de outros órgãos em que haja participação pública, sendo que a noção de patrimônio público abrange, para tal efeito, "os bens e direitos de valor econômico, artístico, estético, histórico ou turístico" (art. $1^{\circ}$ e $\$ 1^{\circ}$, da Lei 4.717/65).

Igualmente a ação civil pública (especialmente para o caso de omissões) e, em certos casos, o mandado de segurança coletivo poderão representar canais adequados para que membros da sociedade civil possam controlar ações ou omissões estatais.

Segundo Nalini67, "a Constituição de 1988 fez com que o Judiciário viesse a protagonizar atuação nitidamente política", em razão dos inúmeros instrumentos por ela criados (mandado de injunção, mandado de segurança coletivo, inconstitucionalidade por omissão, ampliação do cabimento da ação popular, aumento do número de legitimados a propor ação direta de inconstitucionalidade, etc.) que têm enorme potencial de gerar atritos com os poderes políticos.

\subsection{A necessidade de proteger as minorias}

Segundo Vital Moreira, no modelo clássico do Estado existia um só povo e só os cidadãos daquele Estado poderiam ter participação no poder. Os direitos políticos pertenciam exclusivamente aos cidadãos. Não havia lugar para o reconhecimento de minorias étnicas, culturais, linguísticas ou religiosas. Havia o povo dominante, a língua oficial, muitas vezes até mesmo uma religião oficial. Porém, tudo isso se alterou modernamente. Especialmente a Europa descobriu e valorizou a diversidade e o pluralismo étnico, linguístico e religioso ${ }^{68}$, passandose a se reconhecer e proteger as minorias. No âmbito do Conselho da Europa foi aprovada uma convenção para a proteção das minorias e outra para a

67 Renato Nalini, A Rebelião da Toga, p. 295.

68 Dworkin refere que "toda democracia contemporânea é uma nação dividida. Somos divididos culturalmente, etnicamente, politicamente e moralmente. Apesar disso, almejamos viver juntos como iguais, e parece absolutamente crucial a esta ambição que nós também aspiremos que os princípios sob os quais nós somos governados nos tratem como iguais" - Ronald Dworkin, Justice in Robes, p. 73. 
proteção das línguas regionais. A generalidade das novas Constituições do Leste Europeu, onde o problema é ainda mais presente, proclama expressamente esse reconhecimento ${ }^{69}$. Lamentavelmente, porém, especialmente nos últimos anos, esse respeito à diversidade e à valorização das diferenças encontra-se em declínio junto a uma parcela da população, que se sente ameaçada pela impressionante migração de pessoas deslocadas do Oriente Médio, do norte da África, das regiões balcânicas, em razão dos conflitos bélicos, religiosos ou em razão da fome e da miséria de seus países de origem.

Pode-se dizer que, como consequência do relativismo cultural que caracteriza a pós-modernidade, o valor tolerância passou a ser um dos grandes vetores do mundo ocidental contemporâneo e um dos eixos centrais da vida política de uma nação, ao menos no plano normativo. Isso porque, como refere Barzotto, "todas as opiniões valorativas carecem de objetividade, tendo, portanto, o mesmo peso, e merecendo a mesma consideração". Segundo esse autor:

Kelsen imagina que não é do interesse da maioria fazer valer sempre a sua vontade, pois isso levaria a minoria a desistir do jogo democrático, tirando a legitimidade deste. A maioria, para manter o seu predomínio, seria levada ao compromisso com a minoria. Ora, o compromisso entre a maioria e a minoria permite a maior efetivação possível das liberdades individuais.70

De acordo com Dworkin ${ }^{71}$, de nada valeria a afirmação da existência de direitos perante o Estado se a este fosse facultado desconhecer tais direitos, sob a alegação de estar agindo em cumprimento da vontade da maioria democrática. Um direito perante o Estado significa poder fazer alguma coisa ainda quando a maioria pensa ser errado fazê-lo ou ainda que a maioria sofra prejuízos com tal ação.

Ora, exatamente por que os direitos fundamentais são direitos contra a maioria, também o poder judiciário, guardião de tais direitos, deve ser um poder virtualmente contra a maioria. Não se pode condenar ou absolver um cidadão apenas por que tais soluções correspondam aos interesses ou à vontade da maioria. Nenhuma maioria, por mais esmagadora que seja, pode tornar legítima

69 Vital Moreira, "O futuro da Constituição". In: GRAU, Eros Roberto \& GUERRA FILHO, Willis Santiago (org.): Direito Constitucional - estudos em homenagem a Paulo Bonavides, p. 320.

70 L. F. Barzotto, op. cit, pp. 136/137 e 143.

71 Ronald Dworkin, Taking Rights Seriously (1977), trad. it. di Federico Oriana I diritti presi sul serio, p. 278. 
a condenação de um inocente ou a absolvição de um culpado ${ }^{72}$.

Todas as democracias contemporâneas são democracias constitucionais. Em outras palavras, incorporaram, além do princípio democrático, também o princípio pelo qual existem limites àquilo que a maioria pode fazer. Portanto, o papel da magistratura em uma democracia constitucional é aquele de defender os direitos dos cidadãos também contra a maioria ${ }^{73}$. Como afirmou Livio Pepino ${ }^{74}$, a Constituição é a síntese dos princípios e dos valores sobre os quais, em um determinado momento histórico, se atingiu um consenso geral e, portanto, o quadro daquilo que foi subtraído à regra da maioria.

Consequentemente, a jurisdição pode representar um canal de reivindicação de pretensões de minorias excluídas do circuito político e, como tal, como instrumento essencial ao reforço da taxa de participação e de representatividade do inteiro sistema democrático.

Exatamente para assumir tais funções, extremamente importantes em uma moderna democracia, a jurisdição parece destinada a criar fortes tensões com o poder de maioria e a colocar-se, relativamente a esse, como o polo de uma permanente e vivaz dialética institucional ${ }^{75}$.

Qualquer discurso sobre a soberania popular deveria levar em conta o fato de que inclusive nas democracias ocidentais o poder político não se encontra distribuído de forma equilibrada entre as diversas camadas sociais.

Poder-se-ia, então, perguntar quem ganha e quem perde quando ocorre um deslocamento de poder do legislativo para o judiciário.

Quem dá a resposta é Ronald Dworkin:

... uma vez que, em igualdade de condições, os ricos possuem mais poder do que os pobres sobre o legislativo, pelo menos a longo prazo, subtrair algumas decisões ao legislativo seria, por tais razões, mais vantajoso aos pobres. Os membros da minoria têm, em teoria, muito a ganhar com a transferência de poderes, porque a inclinação do legislativo diante da maioria trabalha mais duramente contra aqueles, e por tal razão são os seus direitos que tem maior probabilidade de

72 L. Ferrajoli, "Giurisdizione e democrazia”, Democrazia e Diritto, 1997, n. 1, p. 292.

73 Nesse sentido, Carlo Guarnieri e Patrizia Pederzoli, La democrazia giudiziaria, p. 127.

74 Livio Pepino, "Compiti della politica...", cit., p. 759.

75 Nello Rossi, "Verso una democrazia maggioritaria. Magistratura e mutamento istituzionale", in: N. Rossi (org.), Giudici e democrazia. La magistratura progressista nel mutamento istituzionale, pp. 22/23. 
serem descurados naquela sede. Se os tribunais assumirem como sua a responsabilidade de proteger os direitos individuais, então as minorias ganharão mais poder político na medida em que tenham efetivo acesso ao judiciário ${ }^{76}$.

Dworkin pensava na situação americana ao fazer as considerações supra. Em sociedades de grave teor de injustiça social e de intensa desigualdade econômica, como é o caso do Brasil e de numerosos outros países afluentes, não são as minorias que não têm um verdadeiro acesso ao poder político, mas sim uma enorme, difusa, silenciosa e apática maioria. Pensamos, contudo, que a visão de Dworkin, anteriormente referida, é ainda mais verdadeira nesta situação.

Parece possível, assim, pensar-se numa nova deontologia profissional do magistrado, na qual a figura do juiz seria vista mais como órgão da sociedade civil do que do Estado, assumindo o magistrado a condição de garante dos direitos dos cidadãos contra os poderes, públicos ou privados ${ }^{77}$.

Não é diverso o pensamento do Prof. Erik Jayme ${ }^{78}$, ao ponderar que na legislação ordinária o cidadão individual encontra-se muito pouco representado e espelhado; dificilmente está em condições de impor seus próprios interesses. Nesse contexto, passa a ser objetivo da jurisdição proteger os direitos das minorias e dos indivíduos, eventualmente trascurados por uma legislação em que decidem as maiorias.

Dentro da mesma linha, Abram Chayes $^{79}$ refere que a Suprema Corte norteamericana, ao decidir o caso United States v. Carolene Products ${ }^{80}$, em 1938, concluiu que os interesses econômicos da classe mais avantajada encontram proteção suficiente no processo político ordinário, junto ao legislativo e ao executivo, em que ordinariamente se encontram muito bem representados. Esta constatação não perdeu seu valor nos dias de hoje. Por isso o poder judiciário deve procurar proteger especialmente outros interesses, das classes menos favorecidas, bem como os de natureza não econômica, que raramente se encontram bem $76 \quad$ R. Dworkin, "Giudici e politica nell'esperienza di common law", in: Mario Bessone e R. Guastini (org.), La regola del caso. Materiali sul ragionamento giuridico, pp. 102 e 103.

77 L. Ferrajoli, "Per una storia delle idee di Magistratura Democratica", in: Nello Rossi (org.), Giudici e democrazia. La magistratura progressista nel mutamento istituzionale, p. 66.

78 Erik Jayme, "Formazione progressiva del diritto internazionale privato da parte dei giudici: l'esperienza americana e tedesca", in: Contratto e impresa, 1988, n. 2, p. 457.

79 Abram Chayes. "How Does the Constitution Establish Justice?", 101 Harv. L. Rev. 1036 (1988).

80304 U.S. 144, 152-54 (1938). 
representados e protegidos junto à classe política.

A independência individual de cada magistrado permite que sejam introduzidos no sistema de valores expressos pela jurisdição também os pontos de vista minoritários na sociedade. Desta forma, por meio da mediação da cultura jurídica, é possível contribuir para que as dinâmicas sociais encontrem possíveis respostas institucionais. Pode-se, assim, favorecer a evolução democrática da sociedade, em vez de fazer crescer e radicalizar os conflitos $^{81}$. Foi assim que procedeu a magistratura, ao reconhecer os direitos companheiros, antes que a legislação reconhecesse efeitos jurídicos às uniões estáveis. É assim que ela está procedendo, ao paulatinamente reconhecer plenos direitos aos homossexuais, inclusive de se casar e de adotarem filhos.

Disto tudo decorre a exigência de fortalecer o 'contrapeso' representado pela jurisdição no quadro de um sistema democrático caracterizado pelo predomínio do executivo. Uma vez que aumentam os grupos que não dispõem de acesso às sedes institucionais e ao processo de tomada de decisões politicamente relevantes, restringindo-se ainda mais os espaços de participação no processo político democrático para os não integrantes da maioria, cresce a necessidade de assegurar também aos excluídos, aos marginais, às minorias, a garantia do respeito e da tutela dos direitos fundamentais por meio do eficaz funcionamento de uma jurisdição subtraída à influência do poder de maioria ${ }^{82}$.

No exercício desta função de controlador, se o judiciário deve realmente proteger as minorias de uma eventual maioria invasiva, então deve ele ser independente não somente dos outros ramos do governo, mas também, eventualmente, desta ocasional vontade popular majoritária. Afinal, "aqueles que querem que os juízes decidam com base na opinião pública majoritária, jamais estiveram na minoria"83.

81 Elena Paciotti, "Ruolo della magistratura in uno stato democratico (alla luce della esperienza italiana nei primi anni '90)", Questione giustizia, n. 2-3, 1994, p. 369/370.

82 Nello Rossi, "Verso una democrazia maggioritaria...", cit., p. 20.

83 Neil K. Sethi, "The Elusive Middle Ground: A Proposed Constitutional Speech Restriction for Judicial Selection”, 145 U. Pa. L. Rev. 711, 727 (1997). 


\subsection{A proteção dos direitos fundamentais ${ }^{84}$}

Segundo Barroso, "a conservação e a promoção dos direitos fundamentais, mesmo contra a vontade das maiorias políticas, é uma condição de funcionamento do constitucionalismo democrático." ${ }^{85}$

A tendência à expansão do conteúdo dos direitos fundamentais, a qual hoje se observa em quase todos os regimes democráticos, tem como consequência o alargamento da intervenção judiciária ${ }^{86}$. Segundo André-Jean Arnaud" , há "uma tendência generalizada em todo o mundo para a democratização, para a proteção dos direitos humanos e um renovado interesse pelo Estado de direito, inclusive com reforço do poder dos juízes". A própria introdução, em 2009, na França, do controle a posteriori da constitucionalidade das leis, embora ainda limitado, fez com que o seu Conseil Constitutionnel passasse a ser visto como uma verdadeira corte constitucional, em condições de proteger os direitos dos cidadãos em casos concretos, e não só abstratamente, como ocorria até então ${ }^{88}$.

As constituições modernas são o lugar dos 'novos' direitos fundamentais. Os litígios de natureza constitucional representam o meio para a sua afirmação,

84 Alerta-se o leitor de que seguimos Ingo Sarlet, autor da melhor e mais profunda obra nacional sobre direitos fundamentais, ao incluir nessa terminologia não só os direitos individuais e coletivos, mas também os direitos sociais, a nacionalidade, os direitos políticos, bem como os direitos-garantia. A esse respeito, v. sua monumental $A$ eficácia dos direitos fundamentais, esp. p. $33 \mathrm{~s}$.

85 Luís Roberto Barroso, "Judicialização, ativismo judicial e legitimidade democrática", in http://www.conjur.com.br/2008-dez-22/judicializacao_ativismo_legitimidade_democratica.

86 Como refere Cançado Trindade, nosso maior especialista em direito internacional dos direitos humanos: "Ao longo das cinco últimas décadas testemunhamos o processo histórico de gradual formação, consolidação, expansão e aperfeiçoamento da proteção internacional dos direitos humanos, conformando um direito de proteção dotado de especificidade própria: o Direito Internacional dos Direitos Humanos. A partir da Declaração Universal dos Direitos Humanos de 1948, e ao longo deste meio século, como resposta às necessidades de proteção, têm-se multiplicado os tratados e instrumentos de direitos humanos. A primeira Conferência Mundial de Direitos Humanos (Teerã, 1968), representou, de certo modo, a gradual passagem da fase legislativa de elaboração dos primeiros instrumentos internacionais de direitos humanos (a exemplo dos dois Pactos das Nações Unidas de 1966), à fase de implementação de tais instrumentos. A segunda Conferência Mundial de Direitos Humanos (Viena, 1993), procedeu a uma reavaliação global da aplicação de tais instrumentos e das perspectivas para o novo século" - Antônio Augusto Cançado Trindade. A proteção internacional dos direitos humanos e o Brasil, p. 146/147. E mais adiante refere o jurista que "No contexto da proteção dos direitos humanos a polêmica clássica entre monistas e dualistas revela-se baseada em falsas premissas e superada: verifica-se aqui uma interação dinâmica entre o direito internacional e o direito interno, e os próprios tratados de direitos humanos significativamente consagram o critério da primazia da norma mais favorável aos seres humanos protegidos, seja ela norma de direito internacional ou de direito interno" - op. cit., p. 163/164.

87 Apud CALMON DE PASSOS, J.J. "Globalização, direito e política". In: LEÃO, Adroaldo \& PAMPLONA FILHO, Rodolfo (Coord.). Globalização e Direito, p. 131, nota de rodapé n. 7.

88 É a observação feita por Elaine Mak, Judicial Decision-Making in a Globalised World - A Comparative Analysis of the Changing Practices of Western Highest Courts, p. 11. 
definição e implementação, o que representa uma significativa transferência de poderes aos juízes ${ }^{89}$. Tão importantes são os direitos fundamentais, que a Suprema Corte de Israel, "in the absence of a Bill of Rights, developed an unwritten one, deducing it from the principle of democracy" ${ }^{\prime \prime 0}$.

John $\mathrm{H}$. Merryman, analisando a tendência de uma evolução convergente entre os países de tradição de civil law e os de common law, identifica uma dessas tendências no fato de que em ambas as tradições cada vez há maior consenso no sentido de uma necessidade de definição e proteção dos direitos fundamentais, sendo crescente a preocupação internacional com a matéria. E isso também, segundo ele, acarreta uma tendência em direção a um maior ativismo judicial ${ }^{91}$.

Segundo uma versão muito difundida, até mesmo regimes autoritários, nas décadas passadas, foram persuadidos a institucionalizar judiciários relativamente independentes, na tentativa de mostrar aos potenciais investidores que eles teriam a garantia de uma proteção legal, por tribunais independentes, aos seus direitos patrimoniais. Tais regimes não só tolerariam, mas até mesmo incentivariam seus tribunais a proteger tais direitos proprietários. A partir desse apoio, os tribunais, por iniciativa própria, tenderiam a estender tal proteção também a outros direitos, de natureza não patrimonial. Buscando manter a imagem da existência de tribunais independentes, tais regimes autoritários tenderiam a aceitar tal movimentação de seu judiciário, o que lhe concederia também um maior protagonismo. Essa versão atualmente está sendo relativizada, havendo estudos que mostram que regimes autoritários sempre mantém um arsenal de instrumentos aptos a controlar, ao menos parcialmente, seu judiciário, evitando que o mesmo lhe escape totalmente do controle, bem como mostram também que os mesmos empresários estrangeiros atraídos pela possibilidade de lucrativos investimentos em tais países, até preferem que os tribunais locais apenas lhe garantam seus direitos proprietários e que não se envolvam com direitos de

89 J. H. Merryman, "How Others Do It...", cit., p. 1871.

90 Trad. livre: "na ausência de um Bill of Rights (catálogo de direitos fundamentais), criou um, não escrito, deduzindo-o do princípio da democracia" - segundo Dieter Grimm, em seu texto introdutório do painel sobre Judicial Activism, no excelente Judges in Contemporary Democracy - an International Conversation, editado por Robert Badinter \& Stephen Breyer, p. 20.

91 John H. Merryman, "On the Convergence (and Divergence) of the Civil Law and the Common Law, in: Mauro Cappelletti (org.): New Perspectives for a Common Law of Europe, p. 195-233, p. 211. 
natureza não proprietária (direito ambiental e direitos trabalhistas, por exemplo) ${ }^{92}$. Isso apenas demonstra que judiciários verdadeiramente independentes e capazes de efetivamente garantir todos os direitos fundamentais, individuais e sociais, somente vicejam em democracias, e que têm potencial para incomodar as elites econômicas e políticas.

Os direitos fundamentais vêm assumindo cada vez mais a natureza de princípios cardeais do ordenamento, orientadores da sua interpretação sistemática e, desta forma, idôneo a conferir à interpretação judicial fundada sobre os mesmos a aptidão para conferir uma unidade harmônica aos vários produtos legislativos, superando a fragmentação que cada vez mais os caracteriza.

Não é nada nova a ideia iluminista do Estado como instrumento construído pelos homens para a proteção e satisfação dos seus direitos fundamentais. Só que hoje estes direitos fundamentais não são mais somente os velhos direitos liberais clássicos (a vida, a liberdade pessoal, as liberdades civis), mas também os novos direitos materiais e sociais (os direitos ao trabalho, à subsistência, à moradia, à saúde, ao salário justo, etc.): em uma palavra, todos aqueles direitos vitais que definem a democracia em sentido material; que são subtraídos ao poder de maioria, porque garantidos a todos; subtraídos também ao mercado, porque indisponíveis; que, por fim, são 'invioláveis', no sentido que a sua violação justifica não simplesmente a crítica e o dissenso, como ocorre nas questões que compete à maioria decidir, mas a desobediência e a resistência. O judiciário pode contribuir para tornar o direito um terreno de batalhas civis e de lutas sociais e políticas ${ }^{93}$.

Assim, sendo a concretização ou a efetivação dos direitos fundamentais na sociedade obrigação de todos os Poderes do Estado, indistintamente, trata-se de missão prioritária especialmente para o Poder Judiciário"94.

$\mathrm{E}$, ao assim agir, não há dúvida de que o Judiciário coloca seu próprio peso na balança da repartição de poderes. Após discorrer sobre o notável impacto da

92 Nesse sentido, os inúmeros estudos reunidos no excelente livro Rule by Law - The Politics of Courts in Authoritarian Regimes, organizado por Tom Ginsburg and Tamir Moustafa. De especial valor a síntese feita por Martin Shapiro, "Courts in Authoritarian Regimes", op. cit., p. 326/335, esp. p. 330.

93 L. Ferrajoli, "Per una storia ...", cit., p. 65 e 77.

94 Marcos Augusto Perez. "O papel do Poder Judiciário na efetividade dos direitos fundamentais", in: $R e-$ vista dos Tribunais - Cadernos de Direito Constitucional e Ciência Política, ano 3, vol. 11, abril-junho de 1995, p. 244. 
integração da Convenção Europeia dos Direitos Humanos ao direito interno francês, e como isso obriga o juiz francês a interpretar o direito interno à luz da referida convenção, e, no limite, deixar de aplicá-lo quando incompatível com a carta europeia de direitos humanos, Garapon refere alguns estudos que analisam a jurisprudência da Corte de Cassação francesa a respeito desse tema e concluem que "o equilíbrio de poderes entre o juiz e o legislador modificou-se em favor do juiz"95.

\subsection{As novas funções do judiciário}

O juiz não é mais somente 'intérprete da lei', mas intérprete e resolutor direto dos conflitos e mediador dos interesses ${ }^{96}$, o que muitas vezes é chamado a fazer mesmo na ausência de texto normativo expresso aplicável ao caso, como sói acontecer com todos os chamados hard cases (casos difíceis).

O Estado contemporâneo, ao lado de sua clássica função de fornecer segurança aos particulares, acabou assumindo prevalentemente as funções de reformulação e de retificação de equilíbrios sociais por meio da distribuição e da redistribuição de recursos ${ }^{97}$. Sendo assim, o valor da certeza do direito tem sua importância reduzida e não deve ser a maior preocupação do juiz. Em uma sociedade cada vez mais marcada pelo pluralismo e pelo dinamismo, também o judiciário, como parte do Estado, deve buscar, no âmbito de suas atribuições, estas reformulações e retificações dos equilíbrios sociais. O que significa interpretar e aplicar a lei não tanto no sentido da manutenção da situação presente (valores caros à ideologia da certeza do direito), mas no sentido de sua mudança, caso isso seja uma consequência dos princípios constitucionais (lembrando-se, por exemplo, que o art. $3^{\circ}$ da Constituição Federal prevê que "Constituem objetivos fundamentais da República Federativa do Brasil: I - construir uma sociedade livre, justa e solidária; II - garantir o desenvolvimento nacional; III - erradicar a pobreza e a marginalização e reduzir as desigualdades sociais e regionais; IV - promover o bem de todos, sem preconceitos de origem, raça, sexo, cor, idade e quaisquer outras formas de discriminação." Se esse horizonte constitui 'objetivo fundamental' da República, e, portanto, missão de todos os poderes constituídos, e se tal horizonte ainda está

95 Antoine Garapon, Les Juges - Um pouvoir irresponsable?, p. 179.

96 Giorgio Rebuffa, La funzione giudiziaria, p. 99.

97 G. Rebuffa, op. cit., p. 155. 
distante da realidade presente, então parece claro que mudanças são necessárias para que se avance naquela direção).

Enquanto antigamente o juiz fosse chamado sobretudo para decidir com o olhar voltado para o passado - de modo, pode-se dizer, 'retrospectivo' -, hoje é frequentemente chamado a escolher, relativamente às possíveis alternativas que Ihe são explicitamente deixadas abertas, aquela que melhor se presta a satisfazer os objetivos prefixados no horizonte constitucional. Assim, transfere-se para o juiz a responsabilidade de considerar as possíveis soluções alternativas, de imaginar as suas respectivas consequências, de avaliá-las e, enfim, tomar uma decisão com o olhar constantemente voltado para o futuro. Ou seja, usa-se uma lógica 'prospectiva' e, sem dúvida, similar àquela que sempre foi considerada como própria e peculiar aos outros atores políticos ${ }^{98}$.

Como referiu Aharon Barak, consagrado jurista e magistrado israelense, tendo presidido sua Suprema Corte até sua aposentadoria, em 2006, o juiz, na maioria dos casos que aprecia, simplesmente aplica a solução legislativa preexistente. Todavia, em alguns casos, dele se exige que crie o direito para o caso. Ao fazêlo, deve o juiz aspirar realizar dois objetivos principais. O primeiro consiste em construir uma ponte para transpor a lacuna existente entre a lei e a realidade social. $O$ juiz deve adaptar o direito às necessidades cambiantes da vida. $O$ segundo é proteger a Constituição e seus valores ${ }^{99}$.

Assim, um repensamento da jurisdição é indispensável exatamente porque se quer uma magistratura capaz de adimplir as funções que lhe impõem os tempos mudados ${ }^{100}$.

Para tanto, torna-se cada vez mais imperioso que o magistrado faça uso também do direito comparado, aprendendo com as lições alheias. Atualmente se nota, especialmente (mas não só) em nível de cortes constitucionais, um intenso diálogo entre cortes supremas. Chega-se a falar em cosmopolitismo constitucional. Anteriormente se percebia uma migração jurídica numa direção praticamente de mão única: dos países europeus para suas colônias. De uns tempos para trás o processo de influências internacionais mudou de recepção para diálogo. Os juízes

98 Carlo Guarnieri e Patrizia Pederzoli, La democrazia giudiziaria, p. 13.

99 Aharon Barak, The Judge in a Democracy, p. 306/307.

100 Stefano Rodotà, "Magistratura e politica in Italia", in: E. Bruti Liberati, A. Ceretti e A. Giasanti (org.), Governo dei giudici. La magistratura tra diritto e politica, p. 29. 
não estão preocupados em importar regras jurídicas (que necessariamente são vinculadas a um território), mas sim estão interessados na recepção de raciocínios jurídicos, usados para confrontar problemas semelhantes ${ }^{101}$.

\section{CONSIDERAÇÕES FINAIS}

Certamente há algum exagero e muita simplificação na afirmação de que, enquanto o século XIX foi o século em que predominou o Legislativo, o século XX representou a supremacia do Executivo, destinando-se o século XXI a ser o século do Judiciário. Todavia, não é exagerado afirmar que cada vez mais o Poder Judiciário - aquele poder invisível e nulo, de que falava Montesquieu, ou the least dangerous branch de que falava Hamilton, no The Federalist -, faz-se presente e atuante na vida de uma nação.

Depois de ter assumido plenamente sua condição de verdadeiro poder, cada vez mais é chamado a exercer a função de autêntico contra-poder, ou seja, um poder que se coloca na condição de controlador dos demais poderes, zelando não só para que não ultrapassem suas competências, mas também para que cumpram estritamente suas funções constitucionais.

Mas também o Judiciário se faz cada vez mais imprescindível para a saudável convivência social, zelando para que sejam respeitados os direitos fundamentais dos cidadãos, não só pelo Estado, mas também pelos demais concidadãos.

Este Judiciário, chamado a desempenhar novas funções, exige um novo magistrado, mais consciente da complexidade do Direito contemporâneo, que não mais pode ser visto como um subsistema isolado dos demais. Cada vez mais o fenômeno jurídico mostra suas interfaces com a política, com a economia, com a sociedade.

E, sobretudo, exige um Juiz comprometido com o valor mor dos ordenamentos jurídicos contemporâneos, qual seja, a dignidade da pessoa humana, com direito a um mínimo existencial e ao pleno respeito aos seus direitos fundamentais.

Afinal de contas, "it has become a truism that the quality of justice depends more

101 Alexis Le Quinio, Recherche sur la circulation des solutions juridiques: le recours au droit compare par les juridictions constitutionnelles, p. 201. 
on the quality of the [persons] who administer the law than on the content of the law they administer"102 (em tradução livre: tornou-se um truísmo dizer que a qualidade da justiça depende mais da qualidade das pessoas que aplicam o Direito, do que do conteúdo do Direito que elas aplicam).

\section{REFERÊNCIAS DAS FONTES CITADAS}

ABRAHAM, Henry J. The Judicial Process - An Introductory Analysis of the Courts of the United States, England, and France., $7^{\mathrm{a}}$ ed., New York - Oxford, Oxford University Press, 1998.

ALPA, Guido. L'arte di giudicare. Bari: Laterza, 1996.

ALLARD, Julie ; GARAPON, Antoine. Les juges dans la mondialisation - La nouvelle révolution du droit. Paris: Seuil/La Republique des Idées, 2005.

BADINTER, Robert \& BREYER, Stephen (ed.), Judges in Contemporary Democracy - an International Conversation. New York: New York University Press, 2004.

BARAK, Aharon. The Judge in a Democracy. New Jersey: Princeton University Press, 2006.

BARROSO, Luís Roberto. "Judicialização, ativismo judicial e legitimidade democrática", in http://www.conjur.com.br/2008-dez-22/judicializacao_ativismo_legitimidade_democratica. Acesso em 28.01.2017.

BARROSO, Luis Roberto. "OSupremo Tribunal Federal em 2016: o ano que custou a acabar", disponível em http://www.migalhas.com.br/arquivos/2017/1/art20170109-01.pdf. Acesso em 28.01.2017.

BARZOTTO, Luiz Fernando. A democracia na Constituição. São Leopoldo: Editora Unisinos, 2003.

BOBBIO, Norberto. Direito e Estado no Pensamento de Emanuel Kant (Diritto e Stato nel Pensiero di Emanuele Kant). Brasília: Ed. Universidade de Brasília, 1984.

BOBBIO, Norberto. "Sulla funzione promozionale del diritto". In: Rivista Trimestrale di Diritto e Procedura Civile, 1969.

BREWER-CARÍAS, Allan R. Constitutional Courts as Positive Legislators - A Comparative Law

102 EVAN HAYNES, The Selection and Tenure of Judges, Newark, NJ, 1944, p. 5, citado por Henry J. Abraham, The Judicial Process, p. 1. 
Study. New York: Cambridge University Press, 2011.

BRUTAU, José Puig. A jurisprudência como fonte do direito (trad. de Lenine Nequete). Porto Alegre: Coleção AJURIS/5, 1977.

CALAMANDREI, Piero. "L'avvenire dei diritti di libertà". Introdução a F. Ruffini, Diritti di libertà. Firenze: La Nuova Italia, 1946.

CALMON DE PASSOS, J.J. "Globalização, direito e política". In: LEÃO, Adroaldo \& PAMPLONA FILHO, Rodolfo (coord.). Globalização e Direito. Rio de Janeiro: Editora Forense, 2002.

CAMPILONGO, Celso Fernandes. Direito e Democracia. São Paulo: Ed. Max Limonad, 1997.

CANÇADO TRINDADE, Antônio Augusto. A proteção internacional dos direitos humanos e o Brasil. $2^{\text {a }}$ Ed. Brasília : Editora Universidade de Brasília, 2000.

CAPPELLETTI, Mauro. Il controllo giudiziario di costituzionalità delle leggi nel diritto comparato. Milano, Giuffrè, 1979.

CAPPELLETTI, Mauro. "Un probleme majeur: controle juridictionnel des lois et principe de democratie. Etude de droit comparé". In: Le pouvoir des juges. Paris, Economica e Presses Universitaires d'Aix-Marseille, 1990.

CAPPELLETTI, Mauro (org.): New Perspectives for a Common Law of Europe. "Introduction". Firenze: Le Monnier, 1978.

CAPPELLETTI, Mauro. "Liberté individuelle et justice sociale dans le procès civil italien", Revue Internationale de Droit Comparé., v. 23, 1971.

CAPPELLETTI, Mauro. "Accesso alla giustizia come programma di riforma e come metodo di pensiero", Rivista di Diritto Processuale, 1982.

CASTANHEIRA NEVES, A. "O papel do jurista no nosso tempo". In: DIGESTA - Escritos acerca do direito, do pensamento jurídico, da sua metodologia e outros, Coimbra: Coimbra Editora, 1995, vol. $1^{\circ}$.

CHAYES, Abram. "How Does the Constitution Establish Justice?". In: Harvard Law Review, vol. 101 (1988).

CHIODI, Giulio M. "Giurisdizione ed equità regolativa". In: LIBERATI, Edmondo, CERETTI, A. Ceretti \& GIASANTI, A. Giasanti (org.), Governo dei giudici. La magistratura tra diritto e politica, Milano, Feltrinelli, 1996.

COELHO, Inocêncio Mártires. Interpretação Constitucional. Porto Alegre: Sérgio Antonio Fabris 
Editor, 2003, $2^{\mathrm{a}}$ ed.

COMPARATO, Fábio Konder. "Ensaio sobre o juízo de constitucionalidade de políticas públicas". In: Revista dos Tribunais, v. 737 (1997), pp. 11-22.

DAWSON, Mark. "The political face of judicial activism: Europe's law-politics imbalance", in: DAWSON, Mark; DE WITTE, Bruno; MUIR, Elise (ed.), Judicial Activism at the European Court of Justice. Cheltenham/UK: Edward Elgar, 2013.

DE VITA, Anna. Vocábulo "Diritto alla casa in diritto comparato". In: Dıgesto, Disc. Priv., Sez. Civ., t. VI.

DENTI, Vittorio. "I procedimenti non giudiziali di conciliazione come istituzioni alternative". In: Rivista di Diritto Processuale, 1980.

DWORKIN, Ronald. Taking Rights Seriously (1977) (trad. it. de Federico Oriana) I diritti presi sul serio. Bologna : Il Mulino, 1992.

DWORKIN, Ronald. "Giudici e politica nell'esperienza di common law". In: BESSONE, Mario \& GUASTINI, Ricardo (org.). La regola del caso- materiali sul ragionamento giuridico, Padova, Cedam, 1995.

DWORKIN, Ronald. Justice in Robes. Cambridge/Ma: Harvard University Press, 2006.

FERRAJOLI, Luigi. Diritto e ragione. Teoria del garantismo penale. Bari: Laterza, (1989), 1997, 4a. ed.

FERRAJOLI, Luigi. "Per una storia delle idee di Magistratura Democratica". In: ROSSI, N. (org.). Giudici e democrazia. La magistratura progressista nel mutamento istituzionale, Milano, FrancoAngeli, 1994.

FERRAJOLI, Luigi. "Giurisdizione e democrazia". In: Democrazia e Diritto, 1997, n. 1.

GARAPON, Antoine. Les Juges - Um pouvoir irresponsable ? Paris : Éd. Nicolas Philippe, 2003.

GEYH, Charles Gardner. When Courts \& Congress Collide - The Struggle for Control of America's Judicial System. Ann Arbor: The University of Michigan Press, 2006.

GINSBURG, Tom; MOUSTAFA, Tamir (Ed.). Rule by Law - The Politics of Courts in Authoritarian Regimes. New York: Cambridge University Press, 2010.

GRAU, Eros Roberto. A ordem econômica na Constituição de 1988 (interpretação e crítica). 2. ed. São Paulo: Revista dos Tribunais, 1991.

GRIMM, Dieter. "Judicial Activism - Introduction". In: BADINTER, Robert \& BREYER, Stephen 
(Ed.). Judges in Contemporary Democracy - an International Conversation. New York: New York University Press, 2004.

GUARNIERI, Carlo e PEDERZOLI, Patrizia, La democrazia giudiziaria, Bologna, Il Mulino, 1997. JACOB, Herbert et al. Courts, Law \& Politics in Comparative Perspective. Chelsea: Yale University Press, 1996.

JAYME, Erik. "Formazione progressiva del diritto internazionale privato da parte dei giudici: l'esperienza americana e tedesca". In: Contratto e impresa, 1988, n. 2.

KELSEN, Hans. "Fundamentos da democracia" (Trad. Jefferson L. Camargo e Marcelo B. Cippola). In: KELSEN, H. A democracia. São Paulo: Martins Fontes, 1993.

KOOPMANS, Tim. Courts and Political Institutions - A Comparative View. New York: Cambridge University Press, 2005.

LE QUINIO, Alexis. Recherche sur la circulation des solutions juridiques: le recours au droit compare par les juridictions constitutionnelles. Clermont-Ferrand: Fontation Varenne, 2011.

LORENZETTI, Ricardo Luis. Fundamentos do direito privado [Las normas fundamentales de derecho privado]. São Paulo: Editora Revista dos Tribunais, 1998.

MAK, Elaine. Judicial Decision-Making in a Globalised World - A Comparative Analysis of the Changing Practices of Western Highest Courts. Portland: Hart Publishing, 2015.

MARTINS-COSTA, Judith. "Bioética e Dignidade da Pessoa Humana: Rumo à Construção do Biodireito". In: Revista da Faculdade de Direito da UFRGS, v. 18 (2000).

MERRYMAN, John Henry. "How Others Do It: the French and German Judiciaries". In: Southern California Law Review, vol 61 (1988).

MERRYMAN, John Henry. "On the Convergence (and Divergence) of the Civil Law and the Common Law. In: CAPPELLETTI, Mauro (Org.): New Perspectives for a Common Law of Europe. Firenze: Le Monnier, 1978, p. 195-233.

NALINI, Renato. A Rebelião da Toga. Campinas: Millennium Ed., 2006.

O'DONNELL, Guillermo. "Afterword", in: SIEDER, Rachel; SCHJOLDEN, Line; ANGELL, Alan (Ed.). The Judicialization of Politics in Latin America. New York: Palgrave Macmillan, 2009.

PACIOTTI, Elena. Ruolo della magistratura in uno stato democratico (alla luce della esperienza italiana nei primi anni '90. In: Questione Giustizia, n. 2-3, 1994, pp. 359-372.

PEPINO, Livio. "Compiti della politica, doveri della giurisdizione", Questione giustizia, n. 4, 1995. 
PEREZ, Marcos Augusto. "O papel do Poder Judiciário na efetividade dos direitos fundamentais". In: Revista dos Tribunais - Cadernos de Direito Constitucional e Ciência Política, ano 3, vol. 11, abril-junho de 1995.

POSNER, Richard A. The Federal Courts - Challenge and Reform, Cambridge, Massachusetts, Harvard Un. Press, 1996.

REBUFFA, Giorgio, La funzione giudiziaria. Torino: G. Giappichelli Ed, 1993.

RODOTÀ, Stefano. "Magistratura e politica in Italia". In: LIBERATI, Edmondo, CERETTI, A. Ceretti \& GIASANTI, A. Giasanti (org.), Governo dei giudici. La magistratura tra diritto e politica, Milano, Feltrinelli, 1996.

ROSSI, Nello. "Verso una democrazia maggioritaria. Magistratura e mutamento istituzionale", in: N. Rossi (Org.), Giudici e democrazia. La magistratura progressista nel mutamento istituzionale. Milano, FrancoAngeli, 1994.

ROUSSEAU, Jean-Jacques. Do contrato social (trad. Lourdes Santos Machado). Coleção Os Pensadores. São Paulo: Nova Cultural, 1991.

SARLET, Ingo Wolfgang. A eficácia dos direitos fundamentais. 6. ed. Porto Alegre: Liv. do Advogado, 2006.

SCARMAN, Lord Leslie. O direito inglês. A nova dimensão. Porto Alegre: Fabris, 1978.

SENESE, Salvatore. "Democrazia, sovranità popolare e giurisdizione". In: Questione giustizia, n. 2, 1987.

SETHI, Neil K. "The Elusive Middle Ground: A Proposed Constitutional Speech Restriction for Judicial Selection". In: University of Pennsylvania Law Review, vol. 145 (1997).

SHAPIRO, Martin, "Courts in Authoritarian Regimes", in: GINSBURG, Tom; MOUSTAFA, Tamir (ed.), Rule by Law - The Politics of Courts in Authoritarian Regimes. New York: Cambridge University Press, 2010.

SIEDER, Rachel; SCHJOLDEN, Line; ANGELL, Alan (Ed.), The Judicialization of Politics in Latin America. New York: Palgrave Macmillan, 2009.

SILVESTRI, Gaetano. "Poteri attivi e poteri moderatori: attualità della distinzione". In: Lorenzo Luatti (Org.), L'equilibrio tra i poteri nei moderni ordinamenti costituzionali. Torino, G. Giappichelli, 1994. 
SORRENTINO, Federico. "L'equilibrio istituzionale fra i poteri e la sua garanzia giurisdizionale". In: LUATTI, Lorenzo (Org.), L'equilibrio tra i poteri nei moderni ordinamenti costituzionali.. Torino, G. Giappichelli, 1994.

TERRÉ, François. "Un juge créateur de droit? Non merci !", in : La création du droit par le juge, volume especial (tome 50), de Archives de philosophie du droit. Paris : Dalloz, 2007.

TROCKER, Nicolò. "La responsabilità del giudice". In: Rivista Trimestrale di Diritto e Procedura Civile, 1982.

VITAL MOREIRA. "O futuro da Constituição". In: GRAU, Eros Roberto \& GUERRA FILHO, Willis Santiago (Org.): Direito Constitucional - estudos em homenagem a Paulo Bonavides. São Paulo: Malheiros Ed., 2001.

WHITTINGTON, Keith E. Political Foundations of Judicial Supremacy - The Presidency, the Supreme Court, and Constitutional leadership in U.S. History. New Jersey: Princeton University Press, 2007.

ZAGREBELSKY, Gustavo. Il diritto mite. Torino, Einaudi, 1992.

ZOLO, Danilo. "Cittadinanza democratica e giurisdizione". In: Nello Rossi (Org.), Giudici e democrazia. La magistratura progressista nel mutamento istituzionale. Milano, FrancoAngeli, 1994.

Recebido em: janeiro/2017

Aprovado em: maio/2017 